\title{
Ubiquitylation of nuclear receptors: new linkages and therapeutic implications
}

\author{
Kyle T Helzer, Christopher Hooper, Shigeki Miyamoto and Elaine T Alarid
}

McArdle Laboratory for Cancer Research, Department of Oncology, 6151 Wisconsin Institutes for Medical Research, University of Wisconsin Carbone Cancer Center, University of Wisconsin-Madison, 1111 Highland Avenue, Madison, Wisconsin 53705, USA

Correspondence should be addressed to E T Alarid

Email

alarid@oncology.wisc.edu

\begin{abstract}
The nuclear receptor (NR) superfamily is a group of transcriptional regulators that control multiple aspects of both physiology and pathology and are broadly recognized as viable therapeutic targets. While receptor-modulating drugs have been successful in many cases, the discovery of new drug targets is still an active area of research, because resistance to NR-targeting therapies remains a significant clinical challenge. Many successful targeted therapies have harnessed the control of receptor activity by targeting events within the NR signaling pathway. In this review, we explore the role of NR ubiquitylation and discuss how the expanding roles of ubiquitin could be leveraged to identify additional entry points to control receptor function for future therapeutic development.
\end{abstract}

Key Words

- E3 ligase

- proteasome

- steroid

- NF-KB

Journal of Molecular Endocrinology (2015) 54, R151-R167

\section{Brief overview of nuclear receptor signaling and drug targets}

Nuclear receptors (NRs) comprise a family of transcriptional regulators that control multiple physiological processes including growth, development, reproduction and metabolism through the control of gene expression (Di Croce et al. 1999, Aranda \& Pascual 2001). The founding member of the family, estrogen receptor alpha $(\mathrm{ER} \alpha)$, was identified via its high affinity binding to radiolabeled estradiol $\left(E_{2}\right)$ (Toft \& Gorski 1966, Jensen et al. 1967). Following the cloning of the gene encoding the glucocorticoid receptor (GR, NR3C1; Miesfeld et al. 1984, Hollenberg et al. 1985), numerous other NRs were identified and combined into a superfamily composed of a total of 48 receptors in mammals, including ER $\alpha$ (NR3A1) and ER $\beta$ (NR3A2), thyroid hormone receptor (TR, NR1A1), progesterone receptor (PR, NR3C3), androgen receptor (AR, NR3C4), retinoic acid receptor (RAR, NR1B1-3), retinoic
$\mathrm{X}$ receptor (RXR, NR2B1-3), vitamin D receptor (VDR, NR1I1), peroxisome proliferator-activated receptors (PPAR, NR1C1-3) and a number of orphan receptors with no known ligands (Evans \& Mangelsdorf 2014). The receptors share a similar architecture consisting of an intrinsically disordered N-terminus, which in some receptors encodes a ligand-independent transactivation domain, a central DNA-binding domain containing two zinc finger motifs, and a C-terminal ligand-binding domain (LBD). The LBD mediates multiple receptor functions, including ligand binding, dimerization, co-regulator interactions and ligand-dependent transcriptional activation function. It is no surprise then that research has focused largely on the LBD and the modulation of receptor actions through both endogenous and synthetic ligands (Gronemeyer et al. 2004, McDonnell \& Wardell 2010).

Published by Bioscientifica Ltd 
The dissection of the molecular events that regulate receptor function has greatly advanced the NR field and contributed significantly to the drug discovery toolbox. Originally, NRs were thought to participate in a relatively simple signal transduction pathway in which activated receptors directly mediated responses in the nucleus through direct DNA binding and transcriptional activation. Though fundamentally correct, the broadening knowledge of components in the NR-activation mechanism has greatly expanded the model and simultaneously expanded the opportunity to control receptor function. In the contemporary model, ligands bind to receptors in the cytoplasm or nucleus or, in some cases, to plasma-membrane-bound receptors. Ligand binding triggers a series of intracellular events, including the release of inactive receptors from heat shock protein (Hsp) complexes, changes to receptor protein conformation, mobilization, dimerization and recruitment of multiprotein transcriptional complexes. The activated NR transcriptional complexes include co-regulators (activators and repressors), chromatin modifying and remodeling complexes, and components of the basal transcriptional machinery. To date, over 300 NR co-regulators have been identified (Jung et al. 2005, Malovannaya et al. 2011; www. nursa.org). Ligand activation of membrane receptors couples receptor activation to intracellular signaling cascades (Hammes \& Levin 2011). Additionally, NRs can be activated indirectly through ligand-independent mechanisms by growth factors. The complexity of NR function and regulation is further expanded by the addition of a temporal component to receptor transcriptional complexes (Métivier et al. 2003, Nagaich et al. 2004). Collectively, the elucidation of this activation cascade forms the basis for the identification of agents targeting receptors at multiple levels, including co-activator interactions (Norris et al. 1999, Parent et al. 2008, Gunther et al. 2009), dimerization, subcellular localization (Tran et al. 2009) and DNA binding (Wang et al. 2006, Mao et al. 2008, Andersen et al. 2010, Caboni \& Lloyd 2013).

Post-translational modifications (PTMs) are another regulatory mechanism governing NR function. PTMs represent an important cross-talk mechanism by which other signaling pathways interface with NR activation. In the case of $E R \alpha$, all domains of the receptor can be phosphorylated in response to ligand and/or growth factor cascades (Ali et al. 1993, Le Goff et al. 1994, Bunone et al. 1996, Weis et al. 1996, Chen et al. 1999, Yudt et al. 1999, Clark et al. 2001, Michalides et al. 2004, Held et al. 2012). Studies in breast cancer cell models have demonstrated that phosphorylation can impact multiple aspects of receptor function, including protein stability, dimerization, DNA binding and co-activator preferences (Arnold et al. 1995, Tzeng \& Klinge 1996, Chen et al. 1999, Henrich et al. 2003, Sheeler et al. 2003, Calligé et al. 2005, Valley et al. 2005, Likhite et al. 2006, Bhatt et al. 2012). ER $\alpha$ is also subject to other modifications, including acetylation (Kim et al. 2006), methylation (Le Romancer et al. 2008, Subramanian et al. 2008), SUMOylation (Sentis et al. 2005, Hilmi et al. 2012) and palmitoylation (Acconcia et al. 2005). Readers are referred to a recent comprehensive review of ER $\alpha$ PTMs (Le Romancer et al. 2011). Importantly, ER $\alpha$ and other NRs are targets of ubiquitylation, a PTM that couples receptor protein turnover and transcriptional function at multiple levels of the receptor signaling pathway.

\section{NR degradation by the ubiquitin-proteasome pathway}

The first studies investigating the mechanisms of NR protein turnover pointed to the role of proteasomes and, subsequently, ubiquitylation in targeting receptors to the degradation pathway. Multiple groups demonstrated that proteasome inhibitors disrupted estrogen-induced decreases in ER $\alpha$ protein levels (Alarid et al. 1999, El Khissiin \& Leclercq 1999, Nawaz et al. 1999a). Subsequently, it was observed that $\operatorname{RAR} \gamma 2$ and $\operatorname{RAR} \alpha$ were down-regulated in response to their ligand, all-trans retinoic acid, and the down-regulation was blocked by proteasome inhibitors, MG132 and lactacystin (Zhu et al. 1999, Kopf et al. 2000). The TR, GR and mineralocorticoid receptor (MR) were also found to be down-regulated in response to ligand binding via a similar pathway (Dace et al. 2000, Wallace \& Cidlowski 2001, Yokota et al. 2004). These studies established the proteasome pathway as a key regulator of NR protein stability (Alarid et al. 2006; Fig. 1). One caveat, however, is that proteasome inhibitor studies also disrupt NR motility and transcription (Lonard et al. 2000, Reid et al. 2003, Elbi et al. 2004, Stavreva et al. 2004). Proteasome inhibitors can also affect NR gene expression and indirectly lead to downstream changes in NR target gene regulation (Powers et al. 2010, Prenzel et al. 2011). Further, the proteasome pathway is not selective for NRs, and inhibition of such a vital cellular function can lead to both inhibition and activation of other signaling pathways, production of reactive oxygen species and induction of apoptosis (Shinohara et al. 1996, Emanuele et al. 2002, Cirit et al. 2012). Recent studies also implicate lysosomes in the degradation of a number of NRs, including $\mathrm{ER} \alpha, \mathrm{AR}$ and GR (He et al. 2011, Totta et al.

Published by Bioscientifica Ltd. 


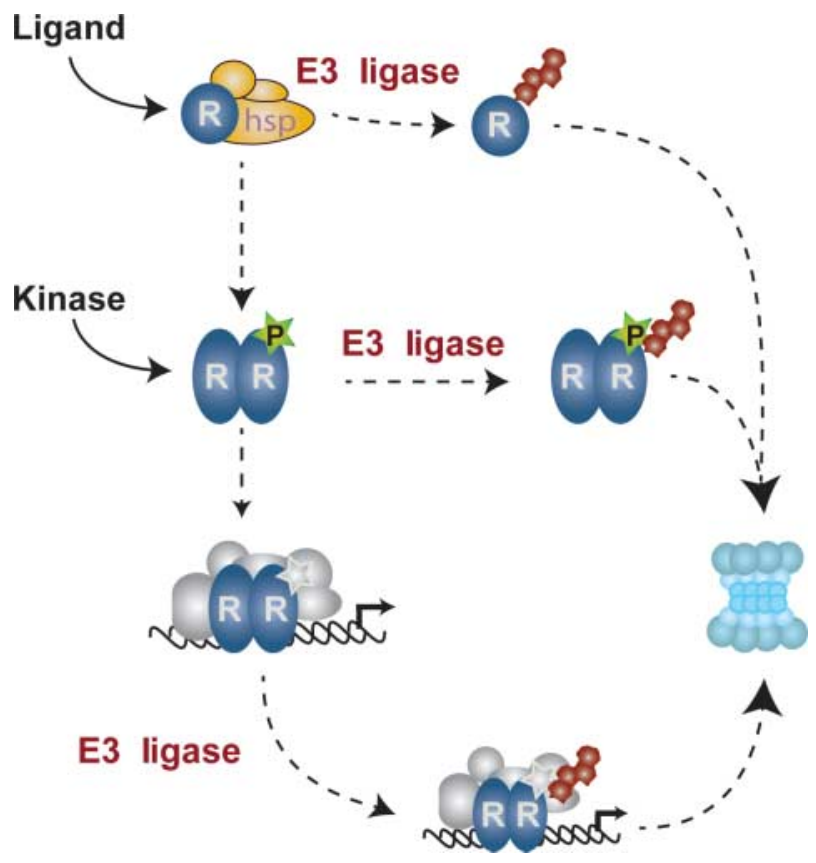

Figure 1

A model of conserved roles of the ubiquitin proteasome pathway in NR signaling. The primary function ascribed to ubiquitin in NR signaling is targeting receptors to the proteasome. Shown here is a simplified NR signaling pathway in which receptor $(R)$ is activated either by ligand or by kinases from growth-factor or membrane-bound NRs. Receptors held bound by heat shock proteins can be targeted for degradation by the $26 \mathrm{~S}$ proteasome following ubiquitylation by E3 ligases, such as CHIP. Upon binding ligand, receptors undergo dimerization (homo- and heterodimerization are not distinguished here) and can be decorated by multiple post-translational modifications (PTMs) including phosphorylation, shown as a star. Phosphorylated receptors can be directly recognized by E3 ligases, ubiquitylated and directed to the proteasome for degradation. Alternatively, PTMs can be incorporated into active transcriptional complexes of variable co-regulator components, represented by a grey multiprotein complex. The make-up of the co-regulator/receptor complexes can recruit E3 ligases that direct ubiquitylation and degradation of the transcriptional complex. In the degradative pathways, PTMs and co-regulator complexes guide $\mathrm{E} 3$ targeting that allows subpopulations of receptors to be selectively degraded in cells.

2014). Owing to the confounding effects of proteasome inhibitors and the complex regulation of NR protein stability, the study of NR proteolysis shifted to better understanding the role and mechanisms of ubiquitylation in targeting NRs to proteasome-mediated degradation.

Ubiquitin is a 76-residue protein that can modify target substrates by covalent attachment of its C-terminal carboxyl group to a lysine residue on the target substrate in a catalytic process involving three classes of enzymes (Hershko \& Ciechanover 1998, Pickart 2001, Komander 2009). The first class of enzymes, known as E1 activating enzymes, bind ubiquitin through a catalytic cysteine residue in an ATP-dependent mechanism, creating a high-energy thioester bond. The E1 enzyme is loaded with a second ubiquitin molecule and then recruits the second class of enzymes, E2 conjugating enzymes. The E1-Ub complex then transfers the ubiquitin to a conserved catalytic cysteine residue of the E2 enzyme, forming a thioester-linked E2-Ub complex in a process known as transthioesterification (Lee \& Schindelin 2008). Lastly, the third class of enzymes, known as E3 ubiquitin ligases, facilitates the transfer of ubiquitin from the E2 conjugating enzyme, directly or indirectly, to a lysine on the substrate forming an isopeptide bond. To date, two ubiquitin-specific E1 activating enzymes (UBA1 and UBA6), 35 E2 conjugating enzymes, and over 600 E3 ligases have been reported in humans (Bernassola et al. 2008, Deshaies \& Joazeiro 2009, Markson et al. 2009, Schulman \& Harper 2009, Ye \& Rape 2009, van Wijk \& Timmers 2010).

Substrate selectivity is primarily guided by E3 ubiquitin ligases, which belong to three subtypes: really interesting new gene (RING), homologous to E6-AP C-terminus (HECT) and RING-between-RING (RBR) (Berndsen \& Wolberger 2014). These ligases are classified based on the corresponding motifs (RING, HECT and RBR) required for E3 activity as well as the distinct mechanisms involved. A RING E3 ligase can function as a monomer, dimer (homo or hetero), or multi-protein complex with the RING domain binding to specific E2s and a distinct region of the ligase (or ligase complex) binding to specific substrates. RING ligases promote the transfer of ubiquitin from ubiquitin-charged E2 without itself forming an intermediate thioester with a ubiquitin molecule. In contrast, HECT ligases accept ubiquitin from ubiquitin-charged E2s to its catalytic cysteine, which is then transferred to the substrate. RBR ligases have a combination of RING and HECT mechanisms whereby one of the RING domains binds to E2s and the other contains a catalytic cysteine that accepts a ubiquitin from ubiquitin-charged E2s and then transfers it to substrates. Table 1 lists the ubiquitin E3 ligases that participate in NR ubiquitylation that are organized by NR types and in a general chronological order of discovery in NR regulation.

In the following sections, we highlight specific ligases that appear to have generalized activities on NRs and that are implicated in distinct aspects of NR signaling pathway with the goal of highlighting processes where interference of NR ubiquitylation may be leveraged as part of on-going drug development targeting the ubiquitin system.

Published by Bioscientifica Ltd. 
Table 1 E3 ligases involved in NR ubiquitylation

\begin{tabular}{|c|c|c|c|c|}
\hline Nuclear receptor & E3 ligase & Class of ligase & Type of Ub & References \\
\hline \multirow[t]{11}{*}{ Estrogen receptor alpha } & E6AP & HECT & Poly & $\begin{array}{l}\text { Nawaz et al. (1999b), Li et al. } \\
\text { (2006), Sun et al. (2012) and } \\
\text { Rajbhandari et al. (2014) }\end{array}$ \\
\hline & CHIP & RING (U-box) & Poly & Fan et al. (2005) \\
\hline & Mdm2 & RING & Poly & Duong et al. (2007) \\
\hline & BRCA1/BARD1 & RING & Mono & Eakin et al. (2007) \\
\hline & EFP (TRIM25) & RING & Poly K48 & Nakajima et al. (2007) \\
\hline & SPOP & RING (Cullin) & Poly & Byun \& Jung (2008) \\
\hline & RBCK1 & RING (RBR) & $?$ & Gustafsson et al. (2010) \\
\hline & CUEDC2 & $?^{\mathrm{a}}$ & $?$ & Pan et al. (2011) \\
\hline & Skp2 & RING (F-box) & Poly & Bhatt et al. (2012) \\
\hline & VHL & RING & Poly & Jung et al. (2012) \\
\hline & RNF31 & RING (RBR) & Mono & Zhu et al. (2014) \\
\hline \multirow[t]{3}{*}{ Estrogen receptor beta } & CHIP & RING (U-box) & Poly K48 & Tateishi et al. (2006) \\
\hline & E6AP & HECT & Poly & Picard et al. (2008) \\
\hline & Mdm2 & RING & Poly & Sanchez et al. (2013) \\
\hline \multirow[t]{7}{*}{ Androgen receptor } & Mdm2 & RING & Poly & Lin et al. (2002) \\
\hline & CHIP & RING (U-box) & Poly & Cardozo et al. (2003) \\
\hline & NEDD4 & HECT & & Li et al. (2008) \\
\hline & RNF6 & RING & Poly K6 or K27 & Xu et al. (2009b) \\
\hline & Siah2 & RING & Poly K48 & Qi et al. (2013) \\
\hline & UBR1 & RING & $?$ & Sultana et al. (2013) \\
\hline & Skp2 & RING & Poly & Li et al. (2014) \\
\hline \multirow[t]{4}{*}{ Glucocorticoid receptor } & $\mathrm{Hdm} 2$ & RING & Poly & Sengupta \& Wasylyk (2001) \\
\hline & CHIP & RING (U-box) & Poly & Connell et al. (2001) \\
\hline & FBXW7 & RING (F-box) & Poly & Malyukova et al. (2013) \\
\hline & UBR1 & RING & $?$ & Sultana et al. (2013) \\
\hline \multirow[t]{2}{*}{ Progesterone receptor } & CUEDC2 & $?^{a}$ & $?$ & Zhang et al. (2007) \\
\hline & BRCA1/BARD1 & RING & Poly & Calvo \& Beato (2011) \\
\hline Retinoic acid receptor alpha & FLRF (Rnf41) & RING & $?$ & Jing et al. (2008) \\
\hline Retinoic X receptor & RNF8 & RING & $?$ & Takano et al. (2004) \\
\hline Mineralocorticoid receptor & CHIP & RING (U-box) & Poly & Faresse et al. (2010) \\
\hline \multirow{2}{*}{$\operatorname{PPAR} \gamma$} & Siah2 & RING & Poly & Kilroy et al. (2012) \\
\hline & MKRN1 & RING & Poly & Kim et al. (2014) \\
\hline Estrogen-related receptors & Parkin & RING (RBR) & Poly & Ren et al. (2011) \\
\hline
\end{tabular}

BARD1, BRCA1-associated RING domain protein 1; BRCA1, breast cancer type 1 susceptibility protein; CHIP, carboxyl terminus of Hsc70-interacting protein; CUEDC2, CUE domain containing 2; E6AP, E6-associated protein; EFP, estrogen-responsive finger protein; FBXW7, F-box/WD repeat-containing protein 7; FLRF, fetal liver ring finger; Hdm2, human double minute 2; HECT, homologous to the E6-AP C-terminus; Mdm2, mouse double minute 2; MKRN1, makorin ring finger protein 1; NEDD4, neural precursor cell expressed, developmentally down-regulated 4; PPAR $\gamma$, peroxisome proliferator-activated receptor gamma; RBCK1, RanBP-type and C3HC4-type zinc finger containing 1; RING, really interesting new gene; RNF6, ring finger protein 6; RNF8, ring finger protein 8; RNF31, ring finger protein 31; Rnf41, ring finger protein 41; Siah2, seven in absentia homolog 2; Skp2, S-phase kinase-associated protein 2; SPOP speckle-type POZ protein; Ub, ubiquitin; UBR1, ubiquitin protein ligase E3 component N-recognin 1; VHL, Von Hipple-Lindau tumor suppressor.

${ }^{a}$ CUEDC2 is a CUE domain-containing gene that promotes the degradation of PR and ER $\alpha$ through ubiquitylation, see references.

\section{Control of unliganded NR protein stability by carboxyl-terminus of Hsc70-interacting protein}

The control of NRs by carboxyl-terminus of Hsc70interacting protein (CHIP) represents specific ligase activity at early stages in NR signaling, including controlling basal NR expression and receptor availability prior to ligand binding. NRs are held stable in their unliganded state by chaperone complexes, which include Hsps, Hsp70 and Hsp90 (Smith \& Toft 1993). The Hsp interaction guides appropriate folding of NR protein and stabilizes the ligand-binding pocket (Bresnick et al. 1989,

http://jme.endocrinology-journals.org
$\begin{array}{lr}\text { DOI: } 10.1530 / \mathrm{JME}-14-0308 & 2015 \text { Society for Endocrinology } \\ & \text { Printed in Great Britain }\end{array}$

Smith 1993, Stancato et al. 1996, Pratt 1997). Disruption of the Hsp90-NR complex using a chemical inhibitor, geldanamycin, was shown to cause down-regulation of $\mathrm{ER} \alpha, \mathrm{PR}, \mathrm{GR}$ and $\mathrm{AR}$ in a proteasome-dependent manner (Whitesell \& Cook 1996, Pratt \& Toft 1997, Bagatell et al. 2001, Connell et al. 2001, Lee et al. 2002, Vanaja et al. 2002, Fan et al. 2005). CHIP is a RING E3 ligase that contains a tetratricopeptide repeat, which binds and decreases the ATPase activity of Hsps. This association ultimately decreases the efficiency of the chaperone and impairs its function, leading to misfolding and subsequent degradation of its substrate by proteasomes (Ballinger et al.

Published by Bioscientifica Ltd. 
1999, Connell et al. 2001). CHIP interacts with Hsp90 and incorporates itself into the NR-Hsp90 heterocomplex, causing remodeling that favors degradation of the NR. In the case of GR, CHIP can ubiquitylate GR both in vitro and in vivo and directly target it for degradation by interacting with the S5a subunit of the $26 \mathrm{~S}$ proteasome (Connell et al. 2001). CHIP was also found to preferentially associate with unliganded $E R \alpha$, increasing ubiquitylation and degradation of the receptor. Other NRs also appear to be ubiquitylated by CHIP, including ER $\beta, A R$, GR and MR, suggesting that ubiquitylation of NRs by CHIP is a conserved mechanism (Cardozo et al. 2003, Wang \& DeFranco 2005, Tateishi et al. 2006, Faresse et al. 2010). Hence, CHIP ligase is a major regulator of unliganded NR protein expression (Fig. 1), which has relevance in scenarios in breast and prostate cancer where therapies such as aromatase inhibitors and abiraterone decrease hormone production yet maintain the unliganded receptor.

\section{Regulated NR ubiquitylation by phosphorylation and coactivator complexes}

Beyond control of basal NR protein levels, ligand-induced turnover of NRs revealed additional layers of complexity in E3 ligase action in NR signaling. As described above, ligand binding to NRs triggers a series of events associated with the transcriptional activation mechanism, including phosphorylation and the recruitment of multi-protein transcriptional complexes. Ubiquitylation is integrated within this activation mechanism through both phosphorylation and the protein complexes recruited to NRs (Fig. 1). For example, the RING E3 ligase mouse double minute $2(\mathrm{Mdm} 2)$ is implicated in the turnover of many NRs, including AR, ER $\alpha, E R \beta$ and GR (Table 1, references therein). The targeting of NRs for ubiquitylation by Mdm2 is triggered by at least two levels of regulation, NR phosphorylation and the composition of the NR transcriptional complex. In the case of AR, phosphorylation of AR on Ser515 by cyclin-dependent kinase 7 (Cdk7), a component of the basal transcriptional machinery, is critical for recruitment of $\mathrm{Mdm} 2$ and the subsequent ubiquitylation and degradation of AR by the proteasome (Chymkowitch et al. 2011). Ubiquitylation of AR by Mdm2 can also be signaled following phosphorylation of AR by Akt on Ser210 and Ser790 (Lin et al. 2002). Mutation of Ser210 and Ser790, or Ser515, to alanine prevents recruitment of Mdm2 and ubiquitylation of $\mathrm{AR}$. Like AR, $\mathrm{Mdm} 2$ is also recruited to $\operatorname{ER} \alpha$ and $\operatorname{ER} \beta$ complexes when the corresponding ER is phosphorylated (Valley et al. 2005,
Picard et al. 2008, Sanchez et al. 2013). However, degradation of ER $\alpha$ upon Mdm2 over-expression provides an example in which specific NR protein complexes are also a requirement for this response - in this case, a complex with p53 (Duong et al. 2007). Similarly, GR degradation following dexamethasone treatment involves the formation of a GR complex containing p53 and Hdm2 (Sengupta \& Wasylyk 2001). In the case of ER $\beta, \mathrm{Mdm} 2$ works in concert with a different coregulator, CREBbinding protein (CBP), to form a complex that results in ubiquitylation and ultimate degradation of ER $\beta$ (Sanchez et al. 2013). Interestingly, unlike ER $\beta$, the Mdm2-CBP complex was unable to target ER $\alpha$ for degradation. These observations suggest that Mdm2 is recruited to NRs as part of larger multi-protein complexes that impart specificity of $\mathrm{Mdm} 2$ action in controlling ubiquitylation and degradation. Given that receptor complexes are dynamic (Métivier et al. 2003), this protein complex specificity, in addition to phosphorylation events, could impart temporal and context-specific regulation on the NR ubiquitylation, stability and associated functions.

Some E3 ligases control NR function through both ligase activity-dependent and -independent mechanisms. A primary example of dual-action E3 ligases is E6associated protein (E6AP). The first studies to demonstrate ubiquitylation of endogenous NRs were done on ER $\alpha$ (Wijayaratne \& McDonnell 2001). Subsequently, E6AP was found to be recruited to $E R \alpha$ in a calmodulin-dependent manner, leading to ubiquitylation and degradation of ER $\alpha$ (Li et al. 2006). In addition to calmodulin-dependent ubiquitylation, recruitment of E6AP to ER $\alpha$ as well as ER $\beta$ requires phosphorylation of the receptor (Picard et al. 2008, Rajbhandari et al. 2014). Consistent with the ligase function of E6AP, mammary and prostate glands of E6APnull mice show elevated levels of ER $\alpha$ (Gao et al. 2005). However, E6AP also functions as a coactivator for $\mathrm{ER} \alpha$, as well as other NRs such as PR, AR and GR (Nawaz et al. 1999b, Ramamoorthy \& Nawaz 2008). In these cases, the disruption of ubiquitin ligase activity as well as the HECT domain of E6AP by mutagenesis had no effect on NR coactivation activity (Nawaz et al. 1999b). Similar ligaseindependent coregulator function has been noted in NR regulation by other HECT ligases, including NEDD4-1, Rsp5 and HACE1. For example, HACE1 was identified as an NR-interacting partner in a yeast two-hybrid screen, and shown to interact with $\operatorname{RAR} \alpha, \operatorname{RAR} \gamma, \mathrm{ER} \alpha$ and $\mathrm{TR} \alpha$. Mutation of critical cysteine residues in the HECT ligase domain had no effect on its transcriptional repressor activity toward RARs (Zhao et al. 2009). Likewise, the ligase activity of Rsp5 is not essential for Rsp5

Published by Bioscientifica Ltd 
coactivation of PR and GR transactivation (Imhof \& McDonnell 1996). Among the HECT ligases, E6AP alone thus far has been directly shown to function as a key NR regulator via ubiquitin ligase-dependent and -independent mechanisms.

\section{Current ubiquitin-targeting therapeutics}

The examples provided above indicate the potential for targeting multiple steps (protein folding, coactivator interactions and transcriptional function) in the NR signaling pathway via control of ubiquitylation. Clinical approaches in cancer therapy have thus far focused on inhibiting the 26S proteasome (Teicher et al. 1999). Bortezomib (Velcade, PS-341) is a general proteasome inhibitor that is FDA approved for the treatment of multiple myeloma and mantle cell lymphoma. Secondgeneration proteasome inhibitors have also been developed, including carfilzomib, which was approved in 2012 for multiple myeloma patients that are refractory to bortezomib therapy (Mitsiades et al. 2011). While the preclinical data supports the efficacy of proteasome inhibitors in other cancer types, the results outside of hematological malignancies have been disappointing (Yang et al. 2006). Hence, efforts are underway to more specifically target the ubiquitylation machinery and their substrates.

A glimpse into the relevance to the NR field is provided by studies of Skp1-Cullin1-F-box (SCF)-Skp2 and p27 $7^{\mathrm{kip} 1}$. Skp2 is an F-box protein and component of the SCF RING ubiquitin E3 ligase complex. Skp2 ligase ubiquitylates and degrades ER $\alpha$ and a high Skp2 expression in human tumors correlates with an ER $\alpha$-negative status (Bhatt et al. 2012). Skp2 is overexpressed in human cancers, and deregulation of Skp2 is implicated in cancer progression through loss of cell-cycle control and transcription (Bloom \& Pagano 2003, Kamata et al. 2005, Davidovich et al. 2008). Skp2 ligase activity was shown to be dependent on $\mathrm{E}_{2}$-induced phosphorylation, leading to ubiquitylation of $\mathrm{p} 27^{\mathrm{kip} 1}$ (Lecanda et al. 2007, Huang et al. 2012). The loss of nuclear p $27^{\text {kip1 }}$ has been shown to occur in $E_{2}$-induced type 1 endometrial carcinogenesis (Lecanda et al. 2007). Using a small molecule screen, specific agents have been identified that block Skp2-dependent ubiquitylation of $\mathrm{p} 27^{\mathrm{kip} 1}$, thus preventing its degradation. Treatment of $\mathrm{E}_{2}$-induced endometrial carcinoma cell lines with these small molecules resulted in increased levels of p27 $7^{\mathrm{kip} 1}$ along with decreased proliferation (Pavlides et al. 2013). These experiments demonstrate that alterations of E3 ligase activity using small molecule inhibitors could be a viable strategy for future therapeutic development. This possibility is further supported by a recent report of peptide and small molecule inhibitors of HECT ligases (Mund et al. 2014).

To date, three E3-targeting drugs have been approved by the FDA, and all three target the same enzyme, cereblon (CRBN). CRBN is a part of the Cul4-Rbx1-DDB1-CRBN RING ubiquitin E3 ligase complex, and the three drugs that target CRBN - thalidomide, lenalidomide and pomalidomide, commonly referred to as immunomodulatory drugs - bind to CRBN and promote the recruitment of substrates, including Ikaros (IKZF1) and Aiolos (IKZF3), which are subsequently ubiquitylated and degraded (Ito et al. 2010, Chamberlain et al. 2014, Fischer et al. 2014, Lu et al. 2014). Currently these drugs are approved for multiple myeloma therapy (Martiniani et al. 2012, Terpos et al. 2013).

\section{Regulation of NR function by E3 ligase-mediated monoubiquitylation}

While the focus in the NR field and therapeutic approaches has largely been directed to the role of ubiquitin in degradation and stability of receptors, the scope of the ubiquitin field extends well beyond degradative mechanisms associated with the proteasome pathway that requires the attachment of a ubiquitin polymer (or chain) with four or more ubiquitin moieties (Thrower et al. 2000). For example, attachment of a single ubiquitin molecule (monoubiquitylation) on NRs by BRCA1 has been described. BRCA1, along with its partner BARD1, form a heterodimeric RING E3 ligase implicated in numerous cellular processes including DNA repair, cell cycle control, transcriptional regulation, apoptosis and genomic stability (Deng 2006, Roy et al. 2012). BRCA1 ubiquitylation of both $\mathrm{ER} \alpha$ and PR contributes to the their transcriptional function (Eakin et al. 2007, Calvo \& Beato 2011). BRCA1/BARD1 monoubiquitylates ER $\alpha$ in vitro and in vivo (Eakin et al. 2007, Dizin \& Irminger-Finger 2010, Ma et al. 2010, Zhu et al. 2014). This monoubiquitylation is dependent on BRCA1/BARD1 ligase activity as cancer predisposing BRCA1 mutations (C61G and C64G) affecting the ligase activity abolish the ability of BRCA1 to monoubiquitylate ER $\alpha$. The site of monoubiquitylation on $\mathrm{ER} \alpha$ was identified through mass spectrometry to be K302; however, the K302A ER $\alpha$ mutant was still monoubiquitylated in vitro. The adjacent lysine residue, K303, can be targeted for monoubiquitylation in lieu of K302 (Eakin et al. 2007). The precise function of ER $\alpha$ monoubiquitylation by BRCA1/BARD1 in vivo is still unclear, although it is hypothesized to play a role in inhibition of

Published by Bioscientifica Ltd. 
$\mathrm{ER} \alpha$ transcriptional activity as well as $\mathrm{E}_{2}$-induced cell proliferation (Ma et al. 2010, La Rosa et al. 2011a). It should be noted, however, that BRCA1 mutant breast cancers are almost always $\mathrm{ER} \alpha$-negative and thus potential therapies targeting the interaction between $\mathrm{ER} \alpha$ and BRCA1 would not be suitable in these cases (Karp et al. 1997, Loman et al. 1998). In the case of PR, BRCA1 induces ubiquitylation, but whether PR ubiquitylation is polyubiquitylation (attachment of a ubiquitin chain on a lysine) or multi-monoubiquitylation (multiple single ubiquitin attachments on different lysine sites on the substrate) is unresolved (Calvo \& Beato 2011).

In addition to BRCA1, RNF31 - also known as HOIP or ZIBRA - can also monoubiquitylate ER $\alpha$ (Zhu et al. 2014). RNF31 is a RBR E3 ligase, and a component of the linear ubiquitin assembly complex (LUBAC). Studies by Zhu et al. (2014) show a positive correlation between RNF31 and ER $\alpha$ levels. Further, manipulation of RNF31 by knockdown or overexpression decreases and increases ER $\alpha$-mediated transcriptional activity, respectively. Importantly, the effects on receptor transcriptional function were shown to be dependent on RNF31 E3 ligase activity, supporting the idea that monoubiquitylation of $\mathrm{ER} \alpha$ can regulate receptor transcriptional activation. The control of ER $\alpha$ by RNF31 and BRCA1/BARD1 suggests that there may be other NRs regulated in the same manner via monoubiquitylation. Moreover, given that RNF31 can act in the context of the LUBAC E3 ligase complex (see below), additional forms of ubiquitylation may also play regulatory roles in NR function.

\section{Non-degradative ubiquitin code}

Advances in the ubiquitin field have led to an emerging concept of the 'ubiquitin code' (Kulathu \& Komander 2012). Ubiquitin itself has seven lysine residues - K6, K11, K27, K29, K33, K48 and K63 - each of which can serve as ubiquitylation sites to assemble ubiquitin chains connected via distinct internal lysine residues (Fig. 2). The attachment of ubiquitin chains linked via lysine K48 marks the substrate for degradation by the $26 \mathrm{~S}$ proteasome and, as mentioned above, a minimum of four ubiquitin molecules is needed for efficient recognition and degradation of substrates tagged with K48-linked polyubiquitin chains (Thrower et al. 2000). The aforementioned NR associated ligases form this type of ubiquitin chains. However, polyubiquitin chains linked by each of the other ubiquitin lysines has been shown to be present in vivo through analysis by mass spectrometry (Xu et al. $2009 a$ ). Moreover, the amino group of the N-terminal methionine of ubiquitin can serve to assemble 'M1-linked' polyubiquitin chains. Many substrates can also be multimonoubiquitylated at multiple lysine sites as described above. Finally, different types of ubiquitin configurations could occur in a single substrate (i.e., 'mixed' ubiquitin linkages). These varying ubiquitin chains significantly expanded the roles that ubiquitin plays in multitudes of molecular, cellular, physiological and pathological processes. The primary decoding of the information built into distinct types of ubiquitin chains is mediated by an array of ubiquitin-binding domains (UBDs) or ubiquitin receptors (Dikic et al. 2009). For a more comprehensive overview of UBDs, we direct the reader to recently published reviews on UBDs (Dikic et al. 2009, Husnjak \& Dikic 2012, Searle et al. 2012). The role for these less commonly studied forms of polyubiquitin linkages in NR regulation is a relatively untapped and emerging area of research. For example, ER $\alpha$ has recently been shown to contain a UBD in its AF-2 domain (Pesiri et al. 2013).

The study of RNF6 in AR biology provides a proof of principle that non-degradative ubiquitin chains can contribute to NR transcriptional function. Xu et al. $(2009 b)$ discovered that AR was polyubiquitylated by the E3 ubiquitin ligase, RNF6, in prostate cancer cells. Following identification as an interacting partner of AR in GST-pull down assays, the authors showed that RNF6 overexpression leads to an increase in polyubiquitylated $\mathrm{AR}$ without changes in AR protein levels. In vitro ubiquitylation assays revealed that RNF6 added K6- or K27-linked polyubiquitin chains to the AR. Overexpression of RNF6 increased the recruitment of co-factors, specifically ARA54, to androgen response elements, which suggests the possibility that specific ubiquitin linkages may contribute to recruitment and specificity of coregulator complexes on DNA. This may have implications in hormone-refractory prostate cancer where RNF6 has been shown to be overexpressed (Xu et al. 2009b).

To begin to elucidate the potential involvement of the ubiquitin code in NR regulation, we briefly provide an example $(\mathrm{NF}-\kappa \mathrm{B})$ where the roles of distinct types of ubiquitylation are better understood (Chen \& Chen 2013). $\mathrm{NF}-\kappa \mathrm{B}$ is a family of related dimeric transcription factors that are held inactive in the cytoplasm by a class of inhibitor proteins, inhibitor of $\kappa \mathrm{B}(\mathrm{I} \kappa \mathrm{B})$. Cell signaling leads to the degradation of $I \kappa B$, liberating NF- $\kappa$ B to the nucleus to initiate transcription. I $\kappa \mathrm{B}$ degradation is mediated by phosphorylation of $I \kappa B$, which creates a docking site for the $\beta$-transducing repeat containing protein $(\beta$-TrCP) RING ubiquitin E3 ligase complex that induces K48-linked polyubiquitylation of $\mathrm{I} \kappa \mathrm{B}$ and its degradation by the $26 \mathrm{~S}$ proteasome. Degradation of

Published by Bioscientifica Ltd 


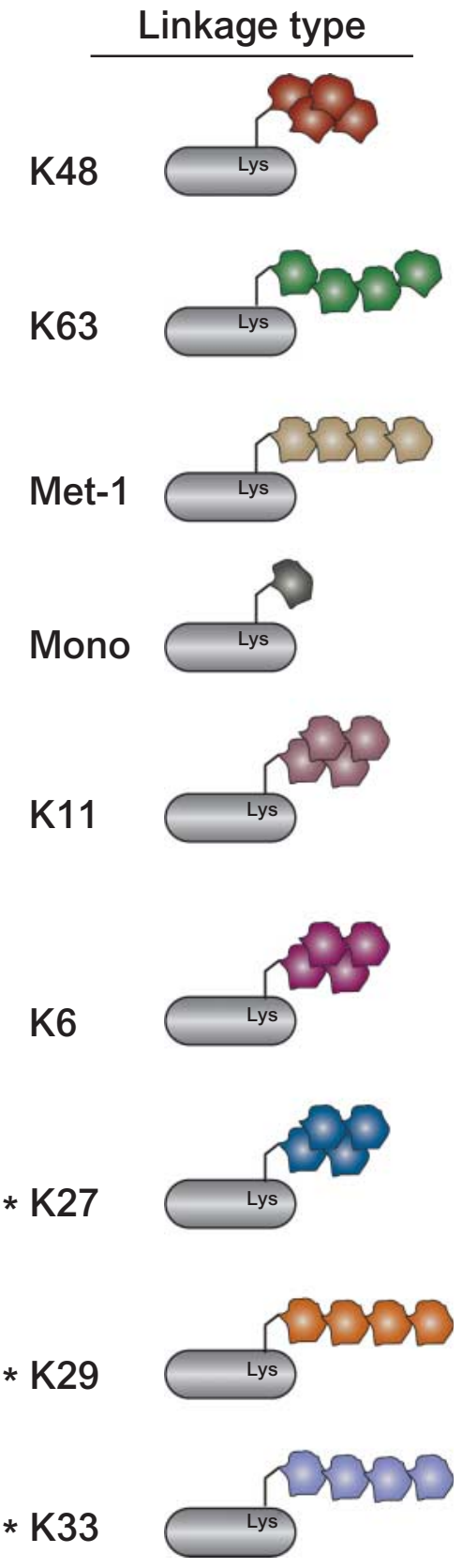

\section{Cellular role \\ Proteasomal degradation \\ Signal transduction \\ Translation \\ Lysosomal degradation \\ Endosomal trafficking \\ DNA damage response}

Signal transduction

Lysosomal degradation
DNA damage response
DNA repair

Cell cycle regulation

Proteasomal degradation

Assembled by APC/C

ERAD

Membrane trafficking

TNF $\alpha$ signaling

DNA repair

DNA damage response

AR transcription

Mitochondrial maintenance

Mitophagy

T-cell (Treg) development

Assembled by parkin

AR transcription

Lysosomal degradation

Ubiquitin-fusion degradation (UFD)

Reduces T-cell activation

\section{References}

Chau et al. (1989)

Peng et al. (2003)

Kim et al. (2011)

Xu et al. (2009a)

Al-Hakim et al. (2010)

Mukhopadhyay \& Riezman (2007)

Spence et al. (2000)

Kirisako et al. (2006)

Tokunaga et al. (2009)

Rahighi et al. (2009)

Emmerich et al. (2013)

Hoege et al. (2002)

Freudenthal et al. (2010)

Jackson \& Durocher (2013)

Jin et al. (2008)

Xu et al. (2009b)

Dynek et al. (2010)

Goto et al. (2010)

Bremm \& Komander (2011)

Wickliffe et al. (2011)

Wu-Baer (2003)

Nishikawa (2003)

Morris \& Solomon (2004)

Sobhian et al. (2007)

Wu et al. (2007)

Xu et al. (2009b)

Xu et al. (2009b)

Geisler et al. (2010)

Durcan et al. (2011)

Glauser et al. (2011)

Peng et al. (2011)

Chastagner et al. (2006)

Al-Hakim et al. (2008)

Licchesi et al. (2011)

Hwang et al. (2010)

Huang et al. (2010)

Licchesi et al. (2011)

\section{Figure 2}

A schematic of the cellular processes in which different polyubiquitin chain species have been implicated based on linkage type. The different types of ubiquitylated species are represented as cartoons in the left-hand column. Polyubiquitin chains can be organized into a 'closed' or 'open' conformation based solely on the type of linkage that connects them.

A (*) symbolizes that structural data is currently unavailable for these

$\mathrm{I} \kappa \mathrm{B}$ is analogous to the polyubiquitylation and degradation of NRs by the proteasome. Interestingly, the mechanism of activation of IKB kinase (IKK) complex that phosphorylates I $\mathrm{KB}$ involves non-degradative polyubiquitin chains, such as K63 and M1 chains, assembled linkages; however, modeling of these structures predicts the conformation of each chain type. Cellular roles are determined based on the identification of each chain type in a specific cellular process. Currently the function of many of these chains is still unknown. This list is not meant to be comprehensive but rather to highlight the many diverse roles of ubiquitin.

by combinations of multiple E2s and E3s. In a simplified model, these polyubiquitin chains are recognized by UBD proteins TAK1 binding proteins 2 and 3 and NF- $\mathrm{BB}$ essential modulator to induce TAK1-dependent IKK activation (Yamaoka et al. 1998; Fig. 3, middle panel).

Published by Bioscientifica Ltd. 


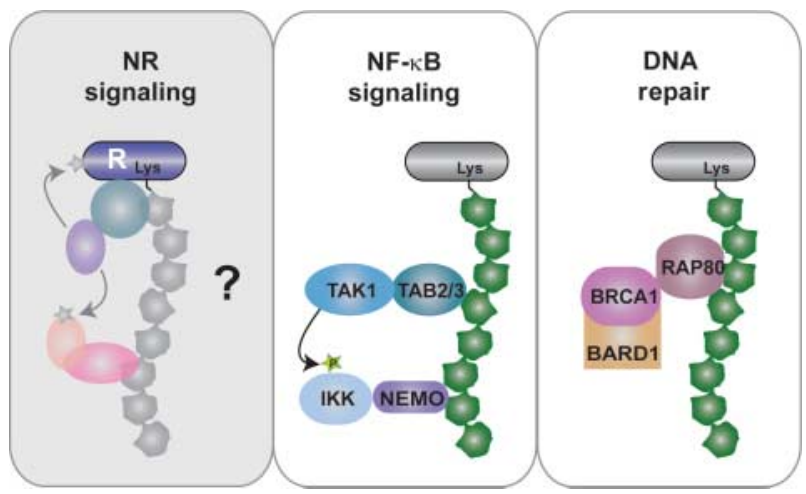

Figure 3

A hypothetical model of non-degradative ubiquitin in NR signaling. Non-degradative polyubiquitin chains can serve as protein assembly scaffolds. Examples shown in the middle and right panels are assemblages described in NF- $\kappa \mathrm{B}$ signaling and DNA damage repair. Based on these models, we speculate the potential for non-degradative ubiquitin chains providing similar scaffolding in NR signaling, bringing together tertiary complexes with enzymatic activity to post-translationally modified receptor or other coregulator proteins to affect transcription. Such scaffolds could also bring other ubiquitin-binding domain (UBD) proteins into the NR complex without directly binding to NR. TAK1, TGF-beta-activated kinase; TAB2/3, TGF-beta activated kinase 1/MAP3K7 binding proteins 2 \& 3; IKK, I-kappa-B kinase complex; NEMO, NF-kappa-B essential modulator; BRCA1, Breast cancer type 1 susceptibility protein; BARD1, BRCA1 associated RING domain 1; Rap80, Receptor-associated protein 80 . Stars represent posttranslational modifications such as phosphorylation, denoted as ' $P$ '.

Thus, NF- $\mathrm{B}$ signaling highlights how non-degradative ubiquitin chains can serve as a novel scaffold to assemble multi-protein complexes. Similarly, non-degradative ubiquitin chains are used to assist in the assembly of protein complexes involved in DNA double-strand break repair (Brown \& Jackson 2015; Fig. 3, right panel). It is conceivable that non-degradative ubiquitin chains could also be used to assist in assembly of NR transcriptional complexes (Fig. 3, left panel).

\section{A new frontier in ubiquitin regulation of NR}

The RNF6 study in AR mentioned above suggests that nondegradative polyubiquitin chains may interface with NR activation mechanisms at the level of co-activators (Xu et al. 2009b). Indeed, an inspection of NR co-activators can identify several of them to contain RING finger domains (Table 2). Whether the RING domains in these coactivators contribute to their activities in NR signaling awaits further investigation. However, intriguingly, TIF1 assembles ternary coactivator complexes as part of AR transcriptional activation (Teyssier et al. 2006), and MAT1 is part of the assembly of TFIIH and Cdk-activating kinase complex involved in receptor phosphorylation and transcriptional synergy (Rochette-Egly et al. 1997, Bastien et al. 2000, Chen et al. 2000, Chymkowitch et al. 2011). It is tempting to speculate that the RING domains of these factors could produce ubiquitin-based assembly scaffolds similar to what is observed in NF- $\mathrm{KB}$ signaling. The limited studies of different ubiquitin linkages in biological contexts, including the NR field, could be due in part to the difficulty in detecting and quantifying endogenous proteins modified by specific ubiquitin linkages. Linkagespecific antibodies are commercially available for the detection of K48, K63 or M1 linkages. These antibodies can be used in immunoprecipitation-western analyses (Haglund \& Dikic 2005, Emmerich et al. 2013, Jackson \& Durocher 2013). This approach has been used to investigate the types of ubiquitin chains formed on ER $\alpha$ in response to $\mathrm{E}_{2}$ (La Rosa et al. 2011b). Alternatively, overexpression and knockdown or knockout of specific E2s and E3s (e.g., Ubc13 for K63 chains or LUBAC subunits for M1 chains; Kirisako et al. 2006, Tokunaga et al. 2009, 2011, Ikeda et al. 2011), or overexpression of ubiquitin

Table 2 NR coregulators that contain RING finger domains

\begin{tabular}{|c|c|c|}
\hline Coregulator & Ring finger designation & Receptor \\
\hline ARNIP & RNF199 & AR \\
\hline BRCA1 & RNF53 & $\begin{array}{l}\mathrm{ER} \alpha \\
\mathrm{PR}\end{array}$ \\
\hline EFP & RNF147 & $\mathrm{ER} \alpha$ \\
\hline MAT1 & RNF66 & $\mathrm{ER} \alpha, \mathrm{PPAR} \gamma$ \\
\hline RNF8 & RNF8 & $\mathrm{R} \times \mathrm{R}$ \\
\hline RLIM & RNF12 & $\mathrm{ER} \alpha$ \\
\hline TIF1 & RNF82 and RNF96 & $\begin{array}{l}\mathrm{RXR}, \mathrm{RAR} \\
\mathrm{ER} \alpha, \mathrm{VDR}, \mathrm{AR} \text { and TR }\end{array}$ \\
\hline SNURF & RNF4 & $\begin{array}{l}\mathrm{AR}, \mathrm{GR} \\
\mathrm{PR} \text { and } \mathrm{ER} \alpha\end{array}$ \\
\hline
\end{tabular}

\begin{tabular}{l} 
References \\
\hline Beitel et al. (2002) \\
Fan et al. (1999), Zheng et al. (2001), Kawai \\
et al. (2002) and Calvo \& Beato (2011) \\
Inoue et al. (1993) and Nakajima et al. (2007) \\
Talukder et al. (2003) and Helenius et al. (2009) \\
Takano et al. (2004) \\
Johnsen et al. (2009) \\
Vom Baur et al. (1996), Thénot et al. (1997) and \\
$\quad$ Teyssier et al. (2006) \\
Moilanen et al. (1998), Poukka et al. (2000) and \\
Saville et al. (2002)
\end{tabular}

RNF, ring finger protein; ARNIP, androgen receptor N-terminal interacting protein; BRCA1, breast cancer type 1 susceptibility protein; EFP, estrogenresponsive finger protein; MAT1, menage-a-trois homologue 1; RLIM, ring finger protein, LIM domain interacting; TIF1, transcriptional intermediary factor; SNURF, SNRPN upstream reading frame.

http://jme.endocrinology-journals.org $\quad$ ○ 2015 Society for Endocrinology
DOI: $10.1530 / J M E-14-0308$
Published by Bioscientifica Ltd 
mutants (K48R, K63R, etc.), as well as replacement of endogenous ubiquitin with ubiquitin mutants ( $\mathrm{Xu}$ et al. 2009c), has been applied to interrogate the role for specific ubiquitin chains. Finally, mass spectrometry techniques have also be used to map the ubiquitylation sites that are aided by the development of anti-di-Gly antibodies to enrich ubiquitylated peptide species following trypsin digestion (Kirkpatrick et al. 2005, Kim et al. 2011). Each of these approaches has limitations in cell systems (e.g., overexpression/knockdown can have effects on multiple substrates, background of endogenous ubiquitin in $\mathrm{mM}$ concentrations, multiple genes encoding ubiquitin, and effects on cell viability). Despite these challenges, in combination these techniques have been instrumental in providing insight into the roles of alternative forms of ubiquitin linkages in cell signaling and regulation.

The role of non-degradative ubiquitin and the ubiquitin code in regulation of NR function is in its infancy and despite some of the current technical challenges, understanding how this protein modification regulates NR function may open new avenues of research and therapeutic design. There are many critical reagents being generated (e.g., antibodies that specifically detect different ubiquitin linkages (Newton et al. 2008, Matsumoto et al. 2012)), new techniques being developed (e.g., advanced, sensitive and quantitative MS analyses (Peng et al. 2003, Xu \& Peng 2006, Phu et al. 2011)) and specific ubiquitin E2s, E3s and deubiquitinases that act on specific ubiquitin linkages are being identified (Komander et al. 2009, Ye \& Rape 2009, Kar et al. 2012). These advances may accelerate the elucidation of the roles for non-degradative polyubiquitylation in regulation of the NR family of proteins. While capitalizing on receptor ubiquitylation has yet to be tapped for clinical application, there is much to be gained by better understanding of the expanding role of ubiquitin in NR signaling. Just as the increased complexity of receptor genomic and non-genomic activities is providing new avenues of rationale design of therapeutics for NR-associated disease, the growing roles of ubiquitin in receptor protein control and transactivation provide an alternative to existing ligand-based therapies. The marriage of NR and ubiquitin fields presents an opportunity for both fields to explore fundamental biology of these important systems with high translational potential.

\section{Declaration of interest}

The authors declare that there is no conflict of interest that could be perceived as prejudicing the impartiality of this review.

\section{Funding}

This work was supported by NIH grants CA159578 (to E T A), F31 CA186551 (to C H), and CA77474 and GM083681 (to S M).

\section{Author contribution statement}

$\mathrm{KT} \mathrm{H}, \mathrm{CH}, \mathrm{S} \mathrm{M}$ and E T A all contributed to writing and editing the manuscript.

\section{Acknowledgements}

We would like to acknowledge Dr Eric Streiter for sharing expertise in ubiquitin linkages. We would also like to acknowledge the support of McArdle Laboratories for Cancer Research and the University of Wisconsin Carbone Cancer Center.

\section{References}

Acconcia F, Ascenzi P, Bocedi A, Spisni E, Tomasi V, Trentalance A, Visca P \& Marino M 2005 Palmitoylation-dependent estrogen receptor $\alpha$ membrane localization: regulation by $17 \beta$-estradiol. Molecular Biology of the Cell 16 231-237. (doi:10.1091/mbc.E04-07-0547)

Alarid ET, Bakopoulos N \& Solodin N 1999 Proteasome-mediated proteolysis of estrogen receptor: a novel component in autologous down-regulation. Molecular Endocrinology 13 1522-1534. (doi:10.1210/ mend.13.9.0337)

Alarid ET, Preisler-Maskek MT \& Solodin NM 2006 Lives and times of nuclear receptors. Molecular Endocrinology 20 1972-1981. (doi:10.1210/ me.2005-0481)

Al-Hakim AK, Zagorska A, Chapman L, Deak M, Peggie M \& Alessi DR 2008 Control of AMPK-related kinases by USP9X and atypical Lys(29)/Lys(33)-linked polyubiquitin chains. Biochemical Journal $\mathbf{4 1 1}$ 249-260. (doi:10.1042/BJ20080067)

Al-Hakim A, Escribano-Diaz C, Landry M-C, O'Donnell L, Panier S, Szilard RK \& Durocher D 2010 The ubiquitous role of ubiquitin in the DNA damage response. DNA Repair 9 1229-1240. (doi:10.1016/j. dnarep.2010.09.011)

Ali S, Metzger D, Bornert JM \& Chambon P 1993 Modulation of transcriptional activation by ligand-dependent phosphorylation of the human oestrogen receptor A/B region. EMBO Journal 12 1153-1160.

Andersen RJ, Mawji NR, Wang J, Wang G, Haile S, Myung J-K, Watt K, Tam T, Yang YC, Bañuelos CA et al. 2010 Regression of castrate-recurrent prostate cancer by a small-molecule inhibitor of the amino-terminus domain of the androgen receptor. Cancer Cell 17 535-546. (doi:10.1016/ j.ccr.2010.04.027)

Aranda A \& Pascual A 2001 Nuclear hormone receptors and gene expression. Physiological Reviews 81 1269-1304.

Arnold SF, Vorojeikina DP \& Notides AC 1995 Phosphorylation of tyrosine 537 on the human estrogen receptor is required for binding to an estrogen response element. Journal of Biological Chemistry 270 30205-30212. (doi:10.1074/jbc.270.4.1850)

Bagatell R, Khan O, Paine-Murrieta G, Taylor CW, Akinaga S \& Whitesell L 2001 Destabilization of steroid receptors by heat shock protein 90-binding drugs: a ligand-independent approach to hormonal therapy of breast cancer. Clinical Cancer Research 7 2076-2084.

Ballinger CA, Connell P, Wu Y, Hu Z, Thompson LJ, Yin LY \& Patterson C 1999 Identification of CHIP, a novel tetratricopeptide repeatcontaining protein that interacts with heat shock proteins and negatively regulates chaperone functions. Molecular and Cellular Biology $194535-4545$.

Bastien J, Adam-Stitah S, Riedl T, Egly JM, Chambon P \& Rochette-Egly C 2000 TFIIH interacts with the retinoic acid receptor $\gamma$ and 
phosphorylates its AF-1-activating domain through cdk7. Journal of Biological Chemistry 275 21896-21904. (doi:10.1074/jbc.M001985200)

Beitel LK, Elhaji YA, Lumbroso R, Wing SS, Panet-Raymond V, Gottlieb B, Pinsky L \& Trifiro MA 2002 Cloning and characterization of an androgen receptor $\mathrm{N}$-terminal-interacting protein with ubiquitinprotein ligase activity. Journal of Molecular Endocrinology 29 41-60. (doi:10.1677/jme.0.0290041)

Bernassola F, Karin M, Ciechanover A \& Melino G 2008 The HECT family of E3 ubiquitin ligases: multiple players in cancer development. Cancer Cell 14 10-21. (doi:10.1016/j.ccr.2008.06.001)

Berndsen CE \& Wolberger C 2014 New insights into ubiquitin E3 ligase mechanism. Nature Structural \& Molecular Biology 21 301-307. (doi:10 1038/nsmb.2780)

Bhatt S, Xiao Z, Meng Z \& Katzenellenbogen BS 2012 Phosphorylation by p38 mitogen-activated protein kinase promotes estrogen receptor $\alpha$ turnover and functional activity via the SCFSkp2 proteasomal complex. Molecular and Cellular Biology 32 1928-1943. (doi:10.1128/MCB. 06561-11)

Bloom J \& Pagano M 2003 Deregulated degradation of the cdk inhibitor p27 and malignant transformation. Seminars in Cancer Biology 13 41-47. (doi:10.1016/S1044-579X(02)00098-6)

Bremm A \& Komander D 2011 Emerging roles for Lys11-linked polyubiquitin in cellular regulation. Trends in Biochemical Sciences $\mathbf{3 6}$ 355-363. (doi:10.1016/j.tibs.2011.04.004)

Bresnick EH, Dalman FC, Sanchez ER \& Pratt WB 1989 Evidence that the $90-\mathrm{kDa}$ heat shock protein is necessary for the steroid binding conformation of the L cell glucocorticoid receptor. Journal of Biological Chemistry 264 4992-4997.

Brown JS \& Jackson SP 2015 Ubiquitylation, neddylation and the DNA damage response. Open Biology 5 150018. (doi:10.1098/rsob.150018)

Bunone G, Briand PA, Miksicek RJ \& Picard D 1996 Activation of the unliganded estrogen receptor by EGF involves the MAP kinase pathway and direct phosphorylation. EMBO Journal 15 2174-2183.

Byun B \& Jung Y 2008 Repression of transcriptional activity of estrogen receptor $\alpha$ by a Cullin3/SPOP ubiquitin E3 ligase complex. Molecules and Cells 25 289-293.

Caboni L \& Lloyd DG 2013 Beyond the ligand-binding pocket: targeting alternate sites in nuclear receptors. Medicinal Research Reviews 33 1081-1118. (doi:10.1002/med.21275)

Calligé M, Kieffer I \& Richard-Foy H 2005 CSN5/Jab1 is involved in liganddependent degradation of estrogen receptor $\{\alpha\}$ by the proteasome. Molecular and Cellular Biology 25 4349-4358. (doi:10.1128/MCB.25.11. 4349-4358.2005)

Calvo V \& Beato M 2011 BRCA1 counteracts progesterone action by ubiquitination leading to progesterone receptor degradation and epigenetic silencing of target promoters. Cancer Research 71 3422-3431. (doi:10.1158/0008-5472.CAN-10-3670)

Cardozo CP, Michaud C, Ost MC, Fliss AE, Yang E, Patterson C, Hall SJ \& Caplan AJ 2003 C-terminal Hsp-interacting protein slows androgen receptor synthesis and reduces its rate of degradation. Archives of Biochemistry and Biophysics 410 134-140. (doi:10.1016/S00039861(02)00680-X)

Chamberlain PP, Lopez-Girona A, Miller K, Carmel G, Pagarigan B, ChieLeon B, Rychak E, Corral LG, Ren YJ, Wang M et al. 2014 Structure of the human cereblon-DDB1-lenalidomide complex reveals basis for responsiveness to thalidomide analogs. Nature Structural \& Molecular Biology 21 803-809. (doi:10.1038/nsmb.2874)

Chastagner P, Israël A \& Brou C 2006 Itch/AIP4 mediates Deltex degradation through the formation of K29-linked polyubiquitin chains. EMBO Reports 7 1147-1153. (doi:10.1038/sj.embor.7400822)

Chau V, Tobias JW, Bachmair A, Marriott D, Ecker DJ, Gonda DK \& Varshavsky A 1989 A multiubiquitin chain is confined to specific lysine in a targeted short-lived protein. Science 243 1576-1583. (doi:10.1126/ science.2538923)

Chen J \& Chen ZJ 2013 Regulation of NF-кB by ubiquitination. Current Opinion in Immunology 25 4-12. (doi:10.1016/j.coi.2012.12.005)
Chen D, Pace PE, Coombes RC \& Ali S 1999 Phosphorylation of human estrogen receptor $\alpha$ by protein kinase A regulates dimerization. Molecular and Cellular Biology 19 1002-1015.

Chen D, Riedl T, Washbrook E, Pace PE, Coombes RC, Egly JM \& Ali S 2000 Activation of estrogen receptor $\alpha$ by S118 phosphorylation involves a ligand-dependent interaction with TFIIH and participation of CDK7. Molecular Cell 6 127-137. (doi:10.1016/S1097-2765(05)00004-3)

Chymkowitch P, May NL, Charneau P, Compe E \& Egly J-M 2011 The phosphorylation of the androgen receptor by TFIIH directs the ubiquitin/proteasome process. EMBO Journal 30 468-479. (doi:10.1038/ emboj.2010.337)

Cirit M, Grant KG \& Haugh JM 2012 Systemic perturbation of the ERK signaling pathway by the proteasome inhibitor, MG132. PLoS ONE 7 e50975. (doi:10.1371/journal.pone.0050975)

Clark DE, Poteet-Smith CE, Smith JA \& Lannigan DA 2001 Rsk2 allosterically activates estrogen receptor $\alpha$ by docking to the hormonebinding domain. EMBO Journal 20 3484-3494. (doi:10.1093/emboj/20. 13.3484)

Connell P, Ballinger CA, Jiang J, Wu Y, Thompson LJ, Höhfeld J \& Patterson C 2001 The co-chaperone CHIP regulates protein triage decisions mediated by heat-shock proteins. Nature Cell Biology 3 93-96. (doi:10.1038/35070170)

Dace A, Zhao L, Park KS, Furuno T, Takamura N, Nakanishi M, West BL, Hanover JA \& Cheng S 2000 Hormone binding induces rapid proteasome-mediated degradation of thyroid hormone receptors. PNAS 97 8985-8990. (doi:10.1073/pnas.160257997)

Davidovich S, Ben-Izhak O, Shapira M, Futerman B \& Hershko DD 2008 Over-expression of Skp2 is associated with resistance to preoperative doxorubicin-based chemotherapy in primary breast cancer. Breast Cancer Research 10 R63. (doi:10.1186/bcr2122)

Deng C-X 2006 BRCA1: cell cycle checkpoint, genetic instability, DNA damage response and cancer evolution. Nucleic Acids Research 34 1416-1426. (doi:10.1093/nar/gk1010)

Deshaies RJ \& Joazeiro CAP 2009 RING domain E3 ubiquitin ligases. Annual Review of Biochemistry 78 399-434. (doi:10.1146/annurev.biochem.78. 101807.093809)

Di Croce L, Okret S, Kersten S, Gustafsson JA, Parker M, Wahli W \& Beato M 1999 Steroid and nuclear receptors. EMBO Journal 18 6201-6210. (doi:10.1093/emboj/18.22.6201)

Dikic I, Wakatsuki S \& Walters KJ 2009 Ubiquitin-binding domains - from structures to functions. Nature Reviews. Molecular Cell Biology 10 659-671. (doi:10.1038/nrm2767)

Dizin E \& Irminger-Finger I 2010 Negative feedback loop of BRCA1-BARD1 ubiquitin ligase on estrogen receptor $\alpha$ stability and activity antagonized by cancer-associated isoform of BARD1. International Journal of Biochemistry \& Cell Biology 42 693-700. (doi:10.1016/j.biocel. 2009.12.025)

Duong V, Boulle N, Daujat S, Chauvet J, Bonnet S, Neel H \& Cavaillès V 2007 Differential regulation of estrogen receptor $\alpha$ turnover and transactivation by $\mathrm{Mdm} 2$ and stress-inducing agents. Cancer Research 67 5513-5521. (doi:10.1158/0008-5472.CAN-07-0967)

Durcan TM, Kontogiannea M, Thorarinsdottir T, Fallon L, Williams AJ, Djarmati A, Fantaneanu T, Paulson HL \& Fon EA 2011 The MachadoJoseph disease-associated mutant form of ataxin-3 regulates parkin ubiquitination and stability. Human Molecular Genetics 20 141-154. (doi:10.1093/hmg/ddq452)

Dynek JN, Goncharov T, Dueber EC, Fedorova AV, Izrael-Tomasevic A, Phu L, Helgason E, Fairbrother WJ, Deshayes K, Kirkpatrick DS et al. 2010 c-IAP1 and UbcH5 promote K11-linked polyubiquitination of RIP1 in TNF signalling. EMBO Journal 29 4198-4209. (doi:10.1038/emboj. 2010.300)

Eakin CM, MacCoss MJ, Finney GL \& Klevit RE 2007 Estrogen receptor $\alpha$ is a putative substrate for the BRCA1 ubiquitin ligase. PNAS $\mathbf{1 0 4}$ 5794-5799. (doi:10.1073/pnas.0610887104)

Elbi C, Walker DA, Romero G, Sullivan WP, Toft DO, Hager GL \& DeFranco DB 2004 Molecular chaperones function as steroid receptor

Published by Bioscientifica Ltd. 
nuclear mobility factors. PNAS 101 2876-2881. (doi:10.1073/pnas. 0400116101)

El Khissiin A \& Leclercq G 1999 Implication of proteasome in estrogen receptor degradation. FEBS Letters 448 160-166. (doi:10.1016/S00145793(99)00343-9)

Emanuele S, Calvaruso G, Lauricella M, Giuliano M, Bellavia G, D'Anneo A, Vento R \& Tesoriere G 2002 Apoptosis induced in hepatoblastoma HepG2 cells by the proteasome inhibitor MG132 is associated with hydrogen peroxide production, expression of Bcl-XS and activation of caspase-3. International Journal of Oncology 21 857-865. (doi:10.3892/ ijo.21.4.857)

Emmerich CH, Ordureau A, Strickson S, Arthur JS, Pedrioli PG, Komander D \& Cohen P 2013 Activation of the canonical IKK complex by K63/M1linked hybrid ubiquitin chains. PNAS 110 15247-15252. (doi:10.1073/ pnas.1314715110)

Evans RM \& Mangelsdorf DJ 2014 Nuclear receptors, RXR, and the big bang. Cell 157 255-266. (doi:10.1016/j.cell.2014.03.012)

Fan S, Wang J-A, Yuan R, Ma Y, Meng Q, Erdos MR, Pestell RG, Yuan F, Auborn KJ, Goldberg ID et al. 1999 BRCA1 inhibition of estrogen receptor signaling in transfected cells. Science 284 1354-1356. (doi:10.1126/science.284.5418.1354)

Fan M, Park A \& Nephew KP 2005 CHIP (carboxyl terminus of Hsc70interacting protein) promotes basal and geldanamycin-induced degradation of estrogen receptor- $\alpha$. Molecular Endocrinology 19 2901-2914. (doi:10.1210/me.2005-0111)

Faresse N, Ruffieux-Daidie D, Salamin M, Gomez-Sanchez CE \& Staub O 2010 Mineralocorticoid receptor degradation is promoted by Hsp90 inhibition and the ubiquitin-protein ligase CHIP. American Journal of Physiology. Renal Physiology 299 F1462-F1472. (doi:10.1152/ajprenal. 00285.2010)

Fischer ES, Böhm K, Lydeard JR, Yang H, Stadler MB, Cavadini S, Nagel J, Serluca F, Acker V, Lingaraju GM et al. 2014 Structure of the DDB1CRBN E3 ubiquitin ligase in complex with thalidomide. Nature $\mathbf{5 1 2}$ 49-53. (doi:10.1038/nature13527)

Freudenthal BD, Gakhar L, Ramaswamy S \& Washington MT 2010 Structure of monoubiquitinated PCNA and implications for translesion synthesis and DNA polymerase exchange. Nature Structural \& Molecular Biology 17 479-484. (doi:10.1038/nsmb.1776)

Gao X, Mohsin SK, Gatalica Z, Fu G, Sharma P \& Nawaz Z 2005 Decreased expression of E6-associated protein in breast and prostate carcinomas. Endocrinology 146 1707-1712. (doi:10.1210/en.2004-1198)

Geisler S, Holmström KM, Skujat D, Fiesel FC, Rothfuss OC, Kahle PJ \& Springer W 2010 PINK1/Parkin-mediated mitophagy is dependent on VDAC1 and p62/SQSTM1. Nature Cell Biology 12 119-131. (doi:10.1038/ncb2012)

Glauser L, Sonnay S, Stafa K \& Moore DJ 2011 Parkin promotes the ubiquitination and degradation of the mitochondrial fusion factor mitofusin 1. Journal of Neurochemistry 118 636-645. (doi:10.1111/j. 1471-4159.2011.07318.x)

Goto E, Yamanaka Y, Ishikawa A, Aoki-Kawasumi M, Mito-Yoshida M, Ohmura-Hoshino M, Matsuki Y, Kajikawa M, Hirano H \& Ishido S 2010 Contribution of lysine 11-linked ubiquitination to MIR2-mediated major histocompatibility complex class I internalization. Journal of Biological Chemistry 285 35311-35319. (doi:10.1074/jbc.M110.112763)

Gronemeyer H, Gustafsson J-Å \& Laudet V 2004 Principles for modulation of the nuclear receptor superfamily. Nature Reviews. Drug Discovery 3 950-964. (doi:10.1038/nrd1551)

Gunther JR, Parent AA \& Katzenellenbogen JA 2009 Alternative inhibition of androgen receptor signaling: peptidomimetic pyrimidines as direct androgen receptor/coactivator disruptors. ACS Chemical Biology 4 435-440. (doi:10.1021/cb900043e)

Gustafsson N, Zhao C, Gustafsson J-Å \& Dahlman-Wright K 2010 RBCK1 drives breast cancer cell proliferation by promoting transcription of estrogen receptor $\alpha$ and cyclin B1. Cancer Research 70 1265-1274. (doi:10.1158/0008-5472.CAN-09-2674)
Haglund K \& Dikic I 2005 Ubiquitylation and cell signaling. EMBO Journal 24 3353-3359. (doi:10.1038/sj.emboj.7600808)

Hammes SR \& Levin ER 2011 Minireview: Recent advances in extranuclear steroid receptor actions. Endocrinology 152 4489-4495. (doi:10.1210/ en.2011-1470)

He Y, Xu Y, Zhang C, Gao X, Dykema KJ, Martin KR, Ke J, Hudson EA, Khoo SK, Resau JH et al. 2011 Identification of a lysosomal pathway that modulates glucocorticoid signaling and the inflammatory response. Science Signaling 4 ra44. (doi:10.1126/scisignal.4159ec44)

Held JM, Britton DJ, Scott GK, Lee EL, Schilling B, Baldwin MA, Gibson BW \& Benz CC 2012 Ligand binding promotes CDK-dependent phosphorylation of ER- $\alpha$ on hinge serine 294 but inhibits ligandindependent phosphorylation of serine 305. Molecular Cancer Research 10 1120-1132. (doi:10.1158/1541-7786.MCR-12-0099)

Helenius K, Yang Y, Alasaari J \& Mäkelä TP 2009 Mat1 inhibits peroxisome proliferator-activated receptor $\gamma$-mediated adipocyte differentiation. Molecular and Cellular Biology 29 315-323. (doi:10.1128/ MCB.00347-08)

Henrich LM, Smith JA, Kitt D, Errington TM, Nguyen B, Traish AM \& Lannigan DA 2003 Extracellular signal-regulated kinase 7, a regulator of hormone-dependent estrogen receptor destruction. Molecular and Cellular Biology 23 5979-5988. (doi:10.1128/MCB.23.17.5979-5988. 2003)

Hershko A \& Ciechanover A 1998 The ubiquitin system. Annual Review of Biochemistry 67 425-479. (doi:10.1146/annurev.biochem.67.1.425)

Hilmi K, Hussein N, Mendoza-Sanchez R, El-Ezzy M, Ismail H, Durette C, Bail M, Rozendaal MJ, Bouvier M, Thibault P et al. 2012 Role of SUMOylation in full antiestrogenicity. Molecular and Cellular Biology 32 3823-3837. (doi:10.1128/MCB.00290-12)

Hoege C, Pfander B, Moldovan G-L, Pyrowolakis G \& Jentsch S 2002 RAD6dependent DNA repair is linked to modification of PCNA by ubiquitin and SUMO. Nature 419 135-141. (doi:10.1038/nature00991)

Hollenberg SM, Weinberger C, Ong ES, Cerelli G, Oro A, Lebo R, Thompson EB, Rosenfeld MG \& Evans RM 1985 Primary structure and expression of a functional human glucocorticoid receptor cDNA. Nature 318 635-641. (doi:10.1038/318635a0)

Huang K-T, Pavlides SC, Lecanda J, Blank SV, Mittal KR \& Gold LI 2012 Estrogen and progesterone regulate p27kip1 levels via the ubiquitinproteasome system: pathogenic and therapeutic implications for endometrial cancer. PLOS ONE 7 e46072. (doi:10.1371/journal.pone. 0046072)

Husnjak K \& Dikic I 2012 Ubiquitin-binding proteins: decoders of ubiquitin-mediated cellular functions. Annual Review of Biochemistry $\mathbf{8 1}$ 291-322. (doi:10.1146/annurev-biochem-051810-094654)

Hwang C-S, Shemorry A, Auerbach D \& Varshavsky A 2010 The N-end rule pathway is mediated by a complex of the RING-type Ubr1 and HECT-type Ufd4 ubiquitin ligases. Nature Cell Biology 12 1177-1185. (doi:10.1038/ncb2121)

Ikeda F, Deribe YL, Skånland SS, Stieglitz B, Grabbe C, Franz-Wachtel M, van Wijk SJ, Goswami P, Nagy V, Terzic J et al. 2011 SHARPIN forms a linear ubiquitin ligase complex regulating NF-кB activity and apoptosis. Nature 471 637-641. (doi:10.1038/nature09814)

Imhof MO \& McDonnell DP 1996 Yeast RSP5 and its human homolog hRPF1 potentiate hormone-dependent activation of transcription by human progesterone and glucocorticoid receptors. Molecular and Cellular Biology 16 2594-2605.

Inoue S, Orimo A, Hosoi T, Kondo S, Toyoshima H, Kondo T, Ikegami A, Ouchi Y, Orimo H \& Muramatsu M 1993 Genomic binding-site cloning reveals an estrogen-responsive gene that encodes a RING finger protein. PNAS 90 11117-11121. (doi:10.1073/pnas.90.23.11117)

Ito T, Ando H, Suzuki T, Ogura T, Hotta K, Imamura Y, Yamaguchi Y \& Handa H 2010 Identification of a primary target of thalidomide teratogenicity. Science 327 1345-1350. (doi:10.1126/science.1177319)

Jackson SP \& Durocher D 2013 Regulation of DNA damage responses by ubiquitin and SUMO. Molecular Cell 49 795-807. (doi:10.1016/j.molcel. 2013.01.017) 
Jensen EV, Desombre ER, Kawashima T, Suzuki T, Kyser K \& Jungblut PW 1967 Estrogen-binding substances of target tissues. Science $\mathbf{1 5 8}$ 529-530. (doi:10.1126/science.158.3800.529-c)

Jin L, Williamson A, Banerjee S, Philipp I \& Rape M 2008 Mechanism of ubiquitin-chain formation by the human anaphase-promoting complex. Cell 133 653-665. (doi:10.1016/j.cell.2008.04.012)

Jing X, Infante J, Nachtman RG \& Jurecic R 2008 E3 ligase FLRF (Rnf41) regulates differentiation of hematopoietic progenitors by governing steady-state levels of cytokine and retinoic acid receptors. Experimental Hematology 36 1110-1120. (doi:10.1016/j.exphem.2008.04.001)

Johnsen SA, Güngör C, Prenzel T, Riethdorf S, Riethdorf L, TaniguchiIshigaki N, Rau T, Tursun B, Furlow JD, Sauter G et al. 2009 Regulation of estrogen-dependent transcription by the LIM cofactors CLIM and RLIM in breast cancer. Cancer Research 69 128-136. (doi:10.1158/00085472.CAN-08-1630)

Jung SY, Malovannaya A, Wei J, O’Malley BW \& Qin J 2005 Proteomic analysis of steady-state nuclear hormone receptor coactivator complexes. Molecular Endocrinology 19 2451-2465. (doi:10.1210/me. 2004-0476)

Jung Y-S, Lee S-J, Yoon M-H, Ha NC \& Park B-J 2012 Estrogen receptor $\alpha$ is a novel target of the Von Hippel-Lindau protein and is responsible for the proliferation of VHL-deficient cells under hypoxic conditions. Cell Cycle 11 4462-4473. (doi:10.4161/cc.22794)

Kamata Y, Watanabe J, Nishimura Y, Arai T, Kawaguchi M, Hattori M, Obokata A \& Kuramoto H 2005 High expression of skp2 correlates with poor prognosis in endometrial endometrioid adenocarcinoma. Journal of Cancer Research and Clinical Oncology 131 591-596. (doi:10.1007/s00432-005-0671-2)

Kar G, Keskin O, Nussinov R \& Gursoy A 2012 Human proteome-scale structural modeling of E2-E3 interactions exploiting interface motifs. Journal of Proteome Research 11 1196-1207. (doi:10.1021/pr2009143)

Karp SE, Tonin PN, Bégin LR, Martinez JJ, Zhang JC, Pollak MN \& Foulkes WD 1997 Influence of BRCA1 mutations on nuclear grade and estrogen receptor status of breast carcinoma in Ashkenazi Jewish women. Cancer 80 435-441. (doi:10.1002/(SICI)1097-0142 (19970801)80:3<435::AID-CNCR11 > 3.0.CO;2-Y)

Kawai H, Li H, Chun P, Avraham S \& Avraham HK 2002 Direct interaction between BRCA1 and the estrogen receptor regulates vascular endothelial growth factor (VEGF) transcription and secretion in breast cancer cells. Oncogene 21 7730-7739. (doi:10.1038/sj.onc.1205971)

Kilroy G, Kirk-Ballard H, Carter LE \& Floyd ZE 2012 The ubiquitin ligase Siah2 regulates PPAR $\gamma$ activity in adipocytes. Endocrinology 153 1206-1218. (doi:10.1210/en.2011-1725)

Kim MY, Woo EM, Chong YTE, Homenko DR \& Kraus WL 2006 Acetylation of estrogen receptor $\alpha$ by p300 at lysines 266 and 268 enhances the deoxyribonucleic acid binding and transactivation activities of the receptor. Molecular Endocrinology 20 1479-1493. (doi:10.1210/me. 2005-0531)

Kim W, Bennett EJ, Huttlin EL, Guo A, Li J, Possemato A, Sowa ME, Rad R, Rush J, Comb MJ et al. 2011 Systematic and quantitative assessment of the ubiquitin-modified proteome. Molecular Cell 44 325-340. (doi:10.1016/j.molcel.2011.08.025)

Kim J-H, Park KW, Lee E-W, Jang W-S, Seo J, Shin S, Hwang K-A \& Song J 2014 Suppression of PPAR $\gamma$ through MKRN1-mediated ubiquitination and degradation prevents adipocyte differentiation. Cell Death and Differentiation 21 594-603. (doi:10.1038/cdd.2013.181)

Kirisako T, Kamei K, Murata S, Kato M, Fukumoto H, Kanie M, Sano S, Tokunaga F, Tanaka K \& Iwai K 2006 A ubiquitin ligase complex assembles linear polyubiquitin chains. EMBO Journal 25 4877-4887. (doi:10.1038/sj.emboj.7601360)

Kirkpatrick DS, Denison C \& Gygi SP 2005 Weighing in on ubiquitin: the expanding role of mass-spectrometry-based proteomics. Nature Cell Biology 7 750-757. (doi:10.1038/ncb0805-750)

Komander D 2009 The emerging complexity of protein ubiquitination. Biochemical Society Transactions 37 937. (doi:10.1042/BST0370937)
Komander D, Clague MJ \& Urbé S 2009 Breaking the chains: structure and function of the deubiquitinases. Nature Reviews. Molecular Cell Biology 10 550-563. (doi:10.1038/nrm2731)

Kopf E, Plassat J-L, Vivat V, de The H, Chambon P \& Rochette-Egly C 2000 Dimerization with retinoid $\mathrm{X}$ receptors and phosphorylation modulate the retinoic acid-induced degradation of retinoic acid receptors $\alpha$ and $\gamma$ through the ubiquitin-proteasome pathway. Journal of Biological Chemistry 275 33280-33288. (doi:10.1074/jbc.M002840200)

Kulathu Y \& Komander D 2012 Atypical ubiquitylation - the unexplored world of polyubiquitin beyond Lys48 and Lys63 linkages. Nature Reviews. Molecular Cell Biology 13 508-523. (doi:10.1038/nrm3394)

La Rosa P, Pesiri V, Marino M \& Acconcia F 2011a 17 $\beta$-Estradiol-induced cell proliferation requires estrogen receptor (ER) $\alpha$ monoubiquitination. Cellular Signalling 23 1128-1135. (doi:10.1016/j.cellsig.2011. 02.006)

La Rosa P, Marino M \& Acconcia F $2011 b 17 \beta$-estradiol regulates estrogen receptor $\alpha$ monoubiquitination. IUBMB Life 63 49-53. (doi:10.1002/ iub.414)

Lecanda J, Parekh TV, Gama P, Lin K, Liarski V, Uretsky S, Mittal K \& Gold LI 2007 Transforming growth factor- $\beta$, estrogen, and progesterone converge on the regulation of p27Kip1 in the normal and malignant endometrium. Cancer Research 67 1007-1018. (doi:10.1158/0008-5472. CAN-06-0235)

Lee I \& Schindelin H 2008 Structural insights into E1-catalyzed ubiquitin activation and transfer to conjugating enzymes. Cell 134 268-278. (doi:10.1016/j.cell.2008.05.046)

Lee MO, Kim EO, Kwon HJ, Kim YM, Kang HJ, Kang H \& Lee JE 2002 Radicicol represses the transcriptional function of the estrogen receptor by suppressing the stabilization of the receptor by heat shock protein 90. Molecular and Cellular Endocrinology 188 47-54. (doi:10.1016/S03037207(01)00753-5)

Le Goff P, Montano MM, Schodin DJ \& Katzenellenbogen BS 1994 Phosphorylation of the human estrogen receptor. Identification of hormone-regulated sites and examination of their influence on transcriptional activity. Journal of Biological Chemistry 269 4458-4466.

Le Romancer M, Treilleux I, Leconte N, Robin-Lespinasse Y, Sentis S, Bouchekioua-Bouzaghou K, Goddard S, Gobert-Gosse S \& Corbo L 2008 Regulation of estrogen rapid signaling through arginine methylation by PRMT1. Molecular Cell 31 212-221. (doi:10.1016/j.molcel.2008. 05.025)

Le Romancer M, Poulard C, Cohen P, Sentis S, Renoir J-M \& Corbo L 2011 Cracking the estrogen receptor's posttranslational code in breast tumors. Endocrine Reviews 32 597-622. (doi:10.1210/er.2010-0016)

Li L, Li Z, Howley PM \& Sacks DB 2006 E6AP and calmodulin reciprocally regulate estrogen receptor stability. Journal of Biological Chemistry $\mathbf{2 8 1}$ 1978-1985. (doi:10.1074/jbc.M508545200)

Li H, Xu LL, Masuda K, Raymundo E, McLeod DG, Dobi A \& Srivastava S 2008 A feedback loop between the androgen receptor and a NEDD4binding protein, PMEPA1, in prostate cancer cells. Journal of Biological Chemistry 283 28988-28995. (doi:10.1074/jbc.M710528200)

Li B, Lu W, Yang Q, Yu X, Matusik RJ \& Chen Z 2014 Skp2 regulates androgen receptor through ubiquitin-mediated degradation independent of Akt/mTOR pathways in prostate cancer. Prostate 74 421-432. (doi:10.1002/pros.22763)

Licchesi JD, Mieszczanek J, Mevissen TE, Rutherford TJ, Akutsu M, Virdee S, El Oualid F, Chin JW, Ovaa H, Bienz M et al. 2012 An ankyrin-repeat ubiquitin-binding domain determines TRABID's specificity for atypical ubiquitin chains. Nature Structural \& Molecular Biology 19 62-71. (doi:10.1038/nsmb.2169)

Likhite VS, Stossi F, Kim K, Katzenellenbogen BS \& Katzenellenbogen JA 2006 Kinase-specific phosphorylation of the estrogen receptor changes receptor interactions with ligand, deoxyribonucleic acid, and coregulators associated with alterations in estrogen and tamoxifen activity. Molecular Endocrinology 20 3120-3132. (doi:10.1210/me.2006-0068)

Lin H-K, Wang L, Hu Y-C, Altuwaijri S \& Chang C 2002 Phosphorylationdependent ubiquitylation and degradation of androgen receptor by Akt 
require Mdm2 E3 ligase. EMBO Journal 21 4037-4048. (doi:10.1093/ emboj/cdf406)

Loman N, Johannsson O, Bendahl PO, Borg A, Fernö M \& Olsson H 1998 Steroid receptors in hereditary breast carcinomas associated with BRCA1 or BRCA2 mutations or unknown susceptibility genes. Cancer 83 310-319. (doi:10.1002/(SICI)1097-0142(19980715)83:2<310::AIDCNCR15>3.0.CO;2-W)

Lonard DM, Nawaz Z, Smith CL \& O'Malley BW 2000 The 26S proteasome is required for estrogen receptor- $\alpha$ and coactivator turnover and for efficient estrogen receptor- $\alpha$ transactivation. Molecular Cell 5 939-948. (doi:10.1016/S1097-2765(00)80259-2)

Lu G, Middleton RE, Sun H, Naniong M, Ott CJ, Mitsiades CS, Wong K-K, Bradner JE \& Kaelin WG 2014 The myeloma drug lenalidomide promotes the cereblon-dependent destruction of Ikaros proteins. Science 343 305-309. (doi:10.1126/science.1244917)

Ma Y, Fan S, Hu C, Meng Q, Fuqua SA, Pestell RG, Tomita YA \& Rosen EM 2010 BRCA1 regulates acetylation and ubiquitination of estrogen receptor- $\alpha$. Molecular Endocrinology 24 76-90. (doi:10.1210/me.20090218)

Malovannaya A, Lanz RB, Jung SY, Bulynko Y, Le NT, Chan DW, Ding C, Shi Y, Yucer N, Krenciute G et al. 2011 Analysis of the human endogenous coregulator complexome. Cell 145 787-799. (doi:10.1016/ j.cell.2011.05.006)

Malyukova A, Brown S, Papa R, O'Brien R, Giles J, Trahair TN, Dalla Pozza L, Sutton R, Liu T, Haber M et al. 2013 FBXW7 regulates glucocorticoid response in T-cell acute lymphoblastic leukaemia by targeting the glucocorticoid receptor for degradation. Leukemia 27 1053-1062. (doi:10.1038/leu.2012.361)

Mao C, Patterson NM, Cherian MT, Aninye IO, Zhang C, Montoya JB, Cheng J, Putt KS, Hergenrother PJ, Wilson EM et al. 2008 A new small molecule inhibitor of estrogen receptor $\alpha$ binding to estrogen response elements blocks estrogen-dependent growth of cancer cells. Journal of Biological Chemistry 283 12819-12830. (doi:10.1074/jbc.M709936200)

Markson G, Kiel C, Hyde R, Brown S, Charalabous P, Bremm A, Semple J, Woodsmith J, Duley S, Salehi-Ashtiani K et al. 2009 Analysis of the human E2 ubiquitin conjugating enzyme protein interaction network. Genome Research 19 1905-1911. (doi:10.1101/gr.093963.109)

Martiniani R, Di Loreto V, Di Sano C, Lombardo A \& Liberati AM 2012 Biological activity of lenalidomide and its underlying therapeutic effects in multiple myeloma. Advances in Hematology 2012842945. (doi:10.1155/2012/842945)

Matsumoto ML, Dong KC, Yu C, Phu L, Gao X, Hannoush RN, Hymowitz SG, Kirkpatrick DS, Dixit VM \& Kelley RF 2012 Engineering and structural characterization of a linear polyubiquitin-specific antibody. Journal of Molecular Biology 418 134-144. (doi:10.1016/j.jmb. 2011.12.053)

McDonnell DP \& Wardell SE 2010 The molecular mechanisms underlying the pharmacological actions of ER modulators: implications for new drug discovery in breast cancer. Current Opinion in Pharmacology 10 620-628. (doi:10.1016/j.coph.2010.09.007)

Métivier R, Penot G, Hübner MR, Reid G, Brand H, Kos M \& Gannon F 2003 Estrogen receptor- $\alpha$ directs ordered, cyclical, and combinatorial recruitment of cofactors on a natural target promoter. Cell $\mathbf{1 1 5}$ 751-763. (doi:10.1016/S0092-8674(03)00934-6)

Michalides R, Griekspoor A, Balkenende A, Verwoerd D, Janssen L, Jalink K, Floore A, Velds A, van't Veer L \& Neefjes J 2004 Tamoxifen resistance by a conformational arrest of the estrogen receptor $\alpha$ after PKA activation in breast cancer. Cancer Cell 5 597-605. (doi:10.1016/j.ccr.2004.05.016)

Miesfeld R, Okret S, Wikström AC, Wrange O, Gustafsson JA \& Yamamoto KR 1984 Characterization of a steroid hormone receptor gene and mRNA in wild-type and mutant cells. Nature 312 779-781. (doi:10.1038/312779a0)

Mitsiades CS, Davies FE, Laubach JP, Joshua D, San Miguel J, Anderson KC \& Richardson PG 2011 Future directions of next-generation novel therapies, combination approaches, and the development of personalized medicine in myeloma. Journal of Clinical Oncology 29 1916-1923. (doi:10.1200/JCO.2010.34.0760)

Moilanen AM, Poukka H, Karvonen U, Häkli M, Jänne OA \& Palvimo JJ 1998 Identification of a novel RING finger protein as a coregulator in steroid receptor-mediated gene transcription. Molecular and Cellular Biology 18 5128-5139.

Morris JR \& Solomon E 2004 BRCA1:BARD1 induces the formation of conjugated ubiquitin structures, dependent on K6 of ubiquitin, in cells during DNA replication and repair. Human Molecular Genetics 13 807-817. (doi:10.1093/hmg/ddh095)

Mukhopadhyay D \& Riezman H 2007 Proteasome-independent functions of ubiquitin in endocytosis and signaling. Science 315 201-205. (doi:10.1126/science.1127085)

Mund T, Lewis MJ, Maslen S \& Pelham HR 2014 Peptide and small molecule inhibitors of HECT-type ubiquitin ligases. PNAS 111 16736-16741. (doi:10.1073/pnas.1412152111)

Nagaich AK, Walker DA, Wolford R \& Hager GL 2004 Rapid periodic binding and displacement of the glucocorticoid receptor during chromatin remodeling. Molecular Cell 14 163-174. (doi:10.1016/S10972765(04)00178-9)

Nakajima A, Maruyama S, Bohgaki M, Miyajima N, Tsukiyama T, Sakuragi N \& Hatakeyama S 2007 Ligand-dependent transcription of estrogen receptor $\alpha$ is mediated by the ubiquitin ligase EFP. Biochemical and Biophysical Research Communications 357 245-251. (doi:10.1016/j.bbrc. 2007.03.134)

Nawaz Z, Lonard DM, Dennis AP, Smith CL \& O'Malley BW 1999a Proteasome-dependent degradation of the human estrogen receptor. PNAS 96 1858-1862. (doi:10.1073/pnas.96.5.1858)

Nawaz Z, Lonard DM, Smith CL, Lev-Lehman E, Tsai SY, Tsai M-J \& O'Malley BW 1999b The Angelman syndrome-associated protein, E6-AP, is a coactivator for the nuclear hormone receptor superfamily. Molecular and Cellular Biology 19 1182-1189.

Newton K, Matsumoto ML, Wertz IE, Kirkpatrick DS, Lill JR, Tan J, Dugger D, Gordon N, Sidhu SS, Fellouse FA et al. 2008 Ubiquitin chain editing revealed by polyubiquitin linkage-specific antibodies. Cell 134 668-678. (doi:10.1016/j.cell.2008.07.039)

Nishikawa H, Ooka S, Sato K, Arima K, Okamoto J, Klevit RE, Fukuda M \& Ohta T 2004 Mass spectrometric and mutational analyses reveal Lys-6linked polyubiquitin chains catalyzed by BRCA1-BARD1 ubiquitin ligase. Journal of Biological Chemistry 279 3916-3924. (doi:10.1074/jbc. M308540200)

Norris JD, Paige LA, Christensen DJ, Chang CY, Huacani MR, Fan D, Hamilton PT, Fowlkes DM \& McDonnell DP 1999 Peptide antagonists of the human estrogen receptor. Science 285 744-746. (doi:10.1126/ science.285.5428.744)

Pan X, Zhou T, Tai Y-H, Wang C, Zhao J, Cao Y, Chen Y, Zhang P-J, Yu M, Zhen $\mathrm{C}$ et al. 2011 Elevated expression of CUEDC2 protein confers endocrine resistance in breast cancer. Nature Medicine 17 708-714. (doi:10.1038/nm.2369)

Parent AA, Gunther JR \& Katzenellenbogen JA 2008 Blocking estrogen signaling after the hormone: pyrimidine-core inhibitors of estrogen receptor-coactivator binding. Journal of Medicinal Chemistry $\mathbf{5 1}$ 6512-6530. (doi:10.1021/jm800698b)

Pavlides SC, Huang K-T, Reid DA, Wu L, Blank SV, Mittal K, Guo L, Rothenberg E, Rueda B, Cardozo T et al. 2013 Inhibitors of SCFSkp2/Cks1 E3 ligase block estrogen-induced growth stimulation and degradation of nuclear p27kip1: therapeutic potential for endometrial cancer. Endocrinology 154 4030-4045. (doi:10.1210/en.2013-1757)

Peng J, Schwartz D, Elias JE, Thoreen CC, Cheng D, Marsischky G, Roelofs J, Finley D \& Gygi SP 2003 A proteomics approach to understanding protein ubiquitination. Nature Biotechnology 21 921-926. (doi:10.1038/ nbt849)

Peng D-J, Zeng M, Muromoto R, Matsuda T, Shimoda K, Subramaniam M, Spelsberg TC, Wei W-Z \& Venuprasad K 2011 Noncanonical K27-linked polyubiquitination of TIEG1 regulates Foxp3 expression and tumor

Published by Bioscientifica Ltd. 
growth. Journal of Immunology 186 5638-5647. (doi:10.4049/jimmunol. 1003801)

Pesiri V, Rosa PL, Stano P \& Acconcia F 2013 Identification of an estrogen receptor $\alpha$ non covalent ubiquitin-binding surface: role in $17 \beta$ estradiol-induced transcriptional activity. Journal of Cell Science $\mathbf{1 2 6}$ 2577-2582. (doi:10.1242/jcs.123307)

Phu L, Izrael-Tomasevic A, Matsumoto ML, Bustos D, Dynek JN, Fedorova AV, Bakalarski CE, Arnott D, Deshayes K, Dixit VM et al. 2011 Improved quantitative mass spectrometry methods for characterizing complex ubiquitin signals. Molecular \& Cellular Proteomics 10 M110.003756. (doi:10.1074/mcp.M110.003756)

Picard N, Charbonneau C, Sanchez M, Licznar A, Busson M, Lazennec G \& Tremblay A 2008 Phosphorylation of activation function-1 regulates proteasome-dependent nuclear mobility and E6-associated protein ubiquitin ligase recruitment to the estrogen receptor $\beta$. Molecular Endocrinology 22 317-330. (doi:10.1210/me.2007-0281)

Pickart CM 2001 Mechanisms underlying ubiquitination. Annual Review of Biochemistry 70 503-533. (doi:10.1146/annurev.biochem.70.1.503)

Poukka H, Aarnisalo P, Santti H, Jänne OA \& Palvimo JJ 2000 Coregulator small nuclear RING finger protein (SNURF) enhances Sp1- and steroid receptor-mediated transcription by different mechanisms. Journal of Biological Chemistry 275 571-579. (doi:10.1074/jbc.275.1.571)

Powers GL, Ellison-Zelski SJ, Casa AJ, Lee AV \& Alarid ET 2010 Proteasome inhibition represses ER $\alpha$ gene expression in ER+ cells: a new link between proteasome activity and estrogen signaling in breast cancer. Oncogene 29 1509-1518. (doi:10.1038/onc.2009.434)

Pratt WB 1997 The role of the hsp90-based chaperone system in signal transduction by nuclear receptors and receptors signaling via MAP kinase. Annual Review of Pharmacology and Toxicology 37 297-326. (doi:10.1146/annurev.pharmtox.37.1.297)

Pratt WB \& Toft DO 1997 Steroid receptor interactions with heat shock protein and immunophilin chaperones. Endocrine Reviews 18 306-360. (doi:10.1210/edrv.18.3.0303)

Prenzel T, Begus-Nahrmann Y, Kramer F, Hennion M, Hsu C, Gorsler T, Hintermair C, Eick D, Kremmer E, Simons M et al. 2011 Estrogendependent gene transcription in human breast cancer cells relies upon proteasome-dependent monoubiquitination of histone H2B. Cancer Research 71 5739-5753. (doi:10.1158/0008-5472.CAN-11-1896)

Qi J, Tripathi M, Mishra R, Sahgal N, Fazil L, Ettinger S, Placzek WJ, Claps G, Chung LW, Bowtell D et al. 2013 The E3 ubiquitin ligase Siah2 contributes to castration-resistant prostate cancer by regulation of androgen receptor transcriptional activity. Cancer Cell 23 332-346. (doi:10.1016/j.ccr.2013.02.016)

Rahighi S, Ikeda F, Kawasaki M, Akutsu M, Suzuki N, Kato R, Kensche T, Uejima T, Bloor S, Komander D et al. 2009 Specific recognition of linear ubiquitin chains by NEMO is important for NF- $\kappa$ B activation. Cell 136 1098-1109. (doi:10.1016/j.cell.2009.03.007)

Rajbhandari P, Schalper KA, Solodin NM, Ellison-Zelski SJ, Ping Lu K, Rimm DL \& Alarid ET 2014 Pin1 modulates ER $\alpha$ levels in breast cancer through inhibition of phosphorylation-dependent ubiquitination and degradation. Oncogene 33 1438-1447. (doi:10.1038/onc.2013.78)

Ramamoorthy S \& Nawaz Z 2008 E6-associated protein (E6-AP) is a dual function coactivator of steroid hormone receptors. Nuclear Receptor Signaling 6 e006. (doi:10.1621/nrs.06006)

Reid G, Hübner MR, Métivier R, Brand H, Denger S, Manu D, Beaudouin J, Ellenberg J \& Gannon F 2003 Cyclic proteasome-mediated turnover of unliganded and liganded $\mathrm{ER} \alpha$ on responsive promoters is an integral feature of estrogen signaling. Molecular Cell 11 695-707. (doi:10.1016/ S1097-2765(03)00090-X)

Ren Y, Jiang H, Ma D, Nakaso K \& Feng J 2011 Parkin degrades estrogenrelated receptors to limit the expression of monoamine oxidases. Human Molecular Genetics 20 1074-1083. (doi:10.1093/hmg/ddq550)

Rochette-Egly C, Adam S, Rossignol M, Egly JM \& Chambon P 1997 Stimulation of RAR $\alpha$ activation function AF-1 through binding to the general transcription factor TFIIH and phosphorylation by CDK7. Cell 90 97-107. (doi:10.1016/S0092-8674(00)80317-7) Printed in Great Britain
Roy R, Chun J \& Powell SN 2012 BRCA1 and BRCA2: different roles in a common pathway of genome protection. Nature Reviews. Cancer 12 68-78. (doi:10.1038/nrc3181)

Sanchez M, Picard N, Sauvé K \& Tremblay A 2013 Coordinate regulation of estrogen receptor $\beta$ degradation by $\mathrm{Mdm} 2$ and CREB-binding protein in response to growth signals. Oncogene 32 117-126. (doi:10.1038/onc. 2012.19)

Saville B, Poukka H, Wormke M, Janne OA, Palvimo JJ, Stoner M, Samudio I $\&$ Safe S 2002 Cooperative coactivation of estrogen receptor $\alpha$ in ZR-75 human breast cancer cells by SNURF and TATA-binding protein. Journal of Biological Chemistry 277 2485-2497. (doi:10.1074/jbc. M109021200)

Schulman BA \& Harper JW 2009 Ubiquitin-like protein activation by E1 enzymes: the apex for downstream signalling pathways. Nature Reviews. Molecular Cell Biology 10 319-331. (doi:10.1038/nrm2673)

Searle MS, Garner TP, Strachan J, Long J, Adlington J, Cavey JR, Shaw B \& Layfield R 2012 Structural insights into specificity and diversity in mechanisms of ubiquitin recognition by ubiquitin-binding domains. Biochemical Society Transactions 40 404-408. (doi:10.1042) BST20110729)

Sengupta S \& Wasylyk B 2001 Ligand-dependent interaction of the glucocorticoid receptor with p53 enhances their degradation by Hdm2. Genes and Development 15 2367-2380. (doi:10.1101/gad.202201)

Sentis S, Le Romancer M, Bianchin C, Rostan M-C \& Corbo L 2005 Sumoylation of the estrogen receptor $\alpha$ hinge region regulates its transcriptional activity. Molecular Endocrinology 19 2671-2684. (doi:10.1210/me.2005-0042)

Sheeler CQ, Singleton DW \& Khan SA 2003 Mutation of serines 104, 106, and 118 inhibits dimerization of the human estrogen receptor in yeast. Endocrine Research 29 237-255. (doi:10.1081/ERC-120022321)

Shinohara K, Tomioka M, Nakano H, Toné S, Ito H \& Kawashima S 1996 Apoptosis induction resulting from proteasome inhibition. Biochemical Journal 317 385-388.

Smith DF 1993 Dynamics of heat shock protein 90-progesterone receptor binding and the disactivation loop model for steroid receptor complexes. Molecular Endocrinology 7 1418-1429. (doi:10.1210/mend.7. 11.7906860)

Smith DF \& Toft DO 1993 Steroid receptors and their associated proteins. Molecular Endocrinology 7 4-11. (doi:10.1210/mend.7.1.8446107)

Sobhian B, Shao G, Lilli DR, Culhane AC, Moreau LA, Xia B, Livingston DM \& Greenberg RA 2007 RAP80 targets BRCA1 to specific ubiquitin structures at DNA damage sites. Science 316 1198-1202. (doi:10.1126/ science.1139516)

Spence J, Gali RR, Dittmar G, Sherman F, Karin M \& Finley D 2000 Cell cycle-regulated modification of the ribosome by a variant multiubiquitin chain. Cell 102 67-76. (doi:10.1016/S0092-8674(00)00011-8)

Stancato LF, Silverstein AM, Gitler C, Groner B \& Pratt WB 1996 Use of the thiol-specific derivatizing agent $\mathrm{N}$-iodoacetyl-3-[ $\left[{ }^{125} \mathrm{I}\right]$ iodotyrosine to demonstrate conformational differences between the unbound and hsp90-bound glucocorticoid receptor hormone binding domain. Journal of Biological Chemistry 271 8831-8836. (doi:10.1074/jbc.271.15. 8831)

Stavreva DA, Müller WG, Hager GL, Smith CL \& McNally JG 2004 Rapid glucocorticoid receptor exchange at a promoter is coupled to transcription and regulated by chaperones and proteasomes. Molecular and Cellular Biology 24 2682-2697. (doi:10.1128/MCB.24.7.2682-2697. 2004)

Subramanian K, Jia D, Kapoor-Vazirani P, Powell DR, Collins RE, Sharma D, Peng J, Cheng X \& Vertino PM 2008 Regulation of estrogen receptor $\alpha$ by the SET7 lysine methyltransferase. Molecular Cell 30 336-347. (doi:10.1016/j.molcel.2008.03.022)

Sultana R, Theodoraki MA \& Caplan AJ 2013 Specificity in the actions of the UBR1 ubiquitin ligase in the degradation of nuclear receptors. FEBS Open Bio 3 394-397. (doi:10.1016/j.fob.2013.09.003)

Sun J, Zhou W, Kaliappan K, Nawaz Z \& Slingerland JM 2012 ER $\alpha$ phosphorylation at Y537 by Src triggers E6-AP-ER $\alpha$ binding, ER $\alpha$

Published by Bioscientifica Ltd. 
ubiquitylation, promoter occupancy, and target gene expression. Molecular Endocrinology 26 1567-1577. (doi:10.1210/me.2012-1140)

Takano Y, Adachi S, Okuno M, Muto Y, Yoshioka T, Matsushima-Nishiwaki R, Tsurumi H, Ito K, Friedman SL, Moriwaki H et al. 2004 The RING finger protein, RNF8, interacts with retinoid $\mathrm{X}$ receptor $\alpha$ and enhances its transcription-stimulating activity. Journal of Biological Chemistry 279 18926-18934. (doi:10.1074/jbc.M309148200)

Talukder AH, Mishra SK, Mandal M, Balasenthil S, Mehta S, Sahin AA, Barnes CJ \& Kumar R 2003 MTA1 interacts with MAT1, a cyclindependent kinase-activating kinase complex ring finger factor, and regulates estrogen receptor transactivation functions. Journal of Biological Chemistry 278 11676-11685. (doi:10.1074/jbc.M209570200)

Tateishi Y, Sonoo R, Sekiya Y, Sunahara N, Kawano M, Wayama M, Hirota R, Kawabe Y, Murayama A, Kato S et al. 2006 Turning off estrogen receptor $\beta$-mediated transcription requires estrogen-dependent receptor proteolysis. Molecular and Cellular Biology 26 7966-7976. (doi:10.1128/ МСB.00713-06)

Teicher BA, Ara G, Herbst R, Palombella VJ \& Adams J 1999 The proteasome inhibitor PS-341 in cancer therapy. Clinical Cancer Research 5 2638-2645.

Terpos E, Kanellias N, Christoulas D, Kastritis E \& Dimopoulos MA 2013 Pomalidomide: a novel drug to treat relapsed and refractory multiple myeloma. OncoTargets and Therapy 6 531-538. (doi:10.2147/OTT. S34498)

Teyssier C, Ou C-Y, Khetchoumian K, Losson R \& Stallcup MR 2006 Transcriptional intermediary factor $1 \alpha$ mediates physical interaction and functional synergy between the coactivator-associated arginine methyltransferase 1 and glucocorticoid receptor-interacting protein 1 nuclear receptor coactivators. Molecular Endocrinology 20 1276-1286. (doi:10.1210/me.2005-0393)

Thénot S, Henriquet C, Rochefort H \& Cavaillès V 1997 Differential interaction of nuclear receptors with the putative human transcriptional coactivator hTIF1. Journal of Biological Chemistry 272 12062-12068.

Thrower JS, Hoffman L, Rechsteiner M \& Pickart CM 2000 Recognition of the polyubiquitin proteolytic signal. EMBO Journal 19 94-102. (doi:10.1093/emboj/19.1.94)

Toft D \& Gorski J 1966 A receptor molecule for estrogens: isolation from the rat uterus and preliminary characterization. PNAS $\mathbf{5 5}$ 1574-1581. (doi:10.1073/pnas.55.6.1574)

Tokunaga F, Sakata S, Saeki Y, Satomi Y, Kirisako T, Kamei K, Nakagawa T, Kato M, Murata S, Yamaoka S et al. 2009 Involvement of linear

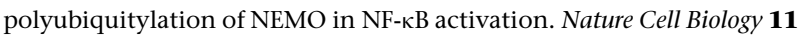
123-132. (doi:10.1038/ncb1821)

Tokunaga F, Nakagawa T, Nakahara M, Saeki Y, Taniguchi M, Sakata S, Tanaka K, Nakano H \& Iwai K 2011 SHARPIN is a component of the NF-кB-activating linear ubiquitin chain assembly complex. Nature $\mathbf{4 7 1}$ 633-636. (doi:10.1038/nature09815)

Totta P, Pesiri V, Marino M \& Acconcia F 2014 Lysosomal function is involved in 17 $\beta$-estradiol-induced estrogen receptor $\alpha$ degradation and cell proliferation. PLOS ONE 9 e94880. (doi:10.1371/journal.pone. 0094880)

Tran C, Ouk S, Clegg NJ, Chen Y, Watson PA, Arora V, Wongvipat J, Smith-Jones PM, Yoo D, Kwon A et al. 2009 Development of a secondgeneration antiandrogen for treatment of advanced prostate cancer. Science 324 787-790. (doi:10.1126/science.1168175)

Tzeng DZ \& Klinge CM 1996 Phosphorylation of purified estradiol-liganded estrogen receptor by casein kinase II increases estrogen response element binding but does not alter ligand stability. Biochemical and Biophysical Research Communications 223 554-560. (doi:10.1006/bbrc. 1996.0933)

Valley CC, Métivier R, Solodin NM, Fowler AM, Mashek MT, Hill L \& Alarid ET 2005 Differential regulation of estrogen-inducible proteolysis and transcription by the estrogen receptor $\alpha \mathrm{N}$ terminus. Molecular and Cellular Biology 25 5417-5428. (doi:10.1128/МСB.25.13.5417. 5428.2005)
Vanaja DK, Mitchell SH, Toft DO \& Young CY 2002 Effect of geldanamycin on androgen receptor function and stability. Cell Stress \& Chaperones 7 55-64. (doi:10.1379/1466-1268(2002)007<0055:EOGOAR > 2.0.CO;2)

Van Wijk SJ \& Timmers HT 2010 The family of ubiquitin-conjugating enzymes (E2s): deciding between life and death of proteins. FASEB Journal 24 981-993. (doi:10.1096/fj.09-136259)

Vom Baur E, Zechel C, Heery D, Heine MJ, Garnier JM, Vivat V, Le Douarin B, Gronemeyer H, Chambon P \& Losson R 1996 Differential liganddependent interactions between the AF-2 activating domain of nuclear receptors and the putative transcriptional intermediary factors mSUG1 and TIF1. EMBO Journal 15 110-124.

Wallace AD \& Cidlowski JA 2001 Proteasome-mediated glucocorticoid receptor degradation restricts transcriptional signaling by glucocorticoids. Journal of Biological Chemistry 276 42714-42721. (doi:10.1074/ jbc.M106033200)

Wang X \& DeFranco DB 2005 Alternative effects of the ubiquitinproteasome pathway on glucocorticoid receptor down-regulation and transactivation are mediated by CHIP, an E3 ligase. Molecular Endocrinology 19 1474-1482. (doi:10.1210/me.2004-0383)

Wang LH, Yang XY, Zhang X, An P, Kim H-J, Huang J, Clarke R, Osborne CK, Inman JK, Appella E et al. 2006 Disruption of estrogen receptor DNAbinding domain and related intramolecular communication restores tamoxifen sensitivity in resistant breast cancer. Cancer Cell 10 487-499. (doi:10.1016/j.ccr.2006.09.015)

Weis KE, Ekena K, Thomas JA, Lazennec G \& Katzenellenbogen BS 1996 Constitutively active human estrogen receptors containing amino acid substitutions for tyrosine 537 in the receptor protein. Molecular Endocrinology 10 1388-1398. (doi:10.1210/mend.10.11.8923465)

Whitesell L \& Cook P 1996 Stable and specific binding of heat shock protein 90 by geldanamycin disrupts glucocorticoid receptor function in intact cells. Molecular Endocrinology 10 705-712. (doi:10.1210/mend. 10.6.8776730)

Wickliffe KE, Williamson A, Meyer H-J, Kelly A \& Rape M 2011 K11-linked ubiquitin chains as novel regulators of cell division. Trends in Cell Biology 21 656-663. (doi:10.1016/j.tcb.2011.08.008)

Wijayaratne AL \& McDonnell DP 2001 The human estrogen receptor- $\alpha$ is a ubiquitinated protein whose stability is affected differentially by agonists, antagonists, and selective estrogen receptor modulators. Journal of Biological Chemistry 276 35684-35692. (doi:10.1074/jbc. M101097200)

Wu W, Nishikawa H, Hayami R, Sato K, Honda A, Aratani S, Nakajima T, Fukuda M \& Ohta T 2007 BRCA1 ubiquitinates RPB8 in response to DNA damage. Cancer Research 67 951-958. (doi:10.1158/0008-5472. CAN-06-3187)

Wu-Baer F, Lagrazon K, Yuan W \& Baer R 2003 The BRCA1/BARD1 heterodimer assembles polyubiquitin chains through an unconventional linkage involving lysine residue K6 of ubiquitin. Journal of Biological Chemistry 278 34743-34746. (doi:10.1074/jbc.C300249200)

Xu P \& Peng J 2006 Dissecting the ubiquitin pathway by mass spectrometry. Biochimica et Biophysica Acta 1764 1940-1947. (doi:10.1016/j.bbapap.2006.09.004)

Xu P, Duong DM, Seyfried NT, Cheng D, Xie Y, Robert J, Rush J, Hochstrasser M, Finley D \& Peng J 2009a Quantitative proteomics reveals the function of unconventional ubiquitin chains in proteasomal degradation. Cell 137 133-145. (doi:10.1016/j.cell.2009.01.041)

Xu K, Shimelis H, Linn DE, Jiang R, Yang X, Sun F, Guo Z, Chen H, Li W, Chen $\mathrm{H}$ et al. $2009 \mathrm{~b}$ Regulation of androgen receptor transcriptional activity and specificity by RNF6-induced ubiquitination. Cancer Cell $\mathbf{1 5}$ 270-282. (doi:10.1016/j.ccr.2009.02.021)

Xu M, Skaug B, Zeng W \& Chen ZJ 2009c A ubiquitin replacement strategy in human cells reveals distinct mechanisms of IKK activation by TNF $\alpha$ and IL-1ß. Molecular Cell 36 302-314. (doi:10.1016/j.molcel.2009.10.002)

Yamaoka S, Courtois G, Bessia C, Whiteside ST, Weil R, Agou F, Kirk HE, Kay RJ \& Israël A 1998 Complementation cloning of NEMO, a

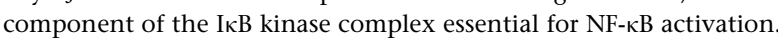
Cell 93 1231-1240. (doi:10.1016/S0092-8674(00)81466-X) 
Yang CH, Gonzalez-Angulo AM, Reuben JM, Booser DJ, Pusztai L, Krishnamurthy S, Esseltine D, Stec J, Broglio KR, Islam R et al. 2006 Bortezomib (VELCADE) in metastatic breast cancer: pharmacodynamics, biological effects, and prediction of clinical benefits. Annals of Oncology 17 813-817. (doi:10.1093/annonc/mdj131)

Ye Y \& Rape M 2009 Building ubiquitin chains: E2 enzymes at work. Nature Reviews. Molecular Cell Biology 10 755-764. (doi:10.1038/ nrm2780)

Yokota K, Shibata H, Kobayashi S, Suda N, Murai A, Kurihara I, Saito I \& Saruta T 2004 Proteasome-mediated mineralocorticoid receptor degradation attenuates transcriptional response to aldosterone. Endocrine Research 30 611-616. (doi:10.1081/ERC-200043783)

Yudt MR, Vorojeikina D, Zhong L, Skafar DF, Sasson S, Gasiewicz TA \& Notides AC 1999 Function of estrogen receptor tyrosine 537 in hormone binding, DNA binding, and transactivation. Biochemistry 38 14146-14156. (doi:10.1021/bi9911132)

Zhang P-J, Zhao J, Li H-Y, Man J-H, He K, Zhou T, Pan X, Li A-L, Gong W-L, Jin B-F et al. 2007 CUE domain containing 2 regulates degradation of progesterone receptor by ubiquitin-proteasome. EMBO Journal 26 1831-1842. (doi:10.1038/sj.emboj.7601602)

Zhao J, Zhang Z, Vucetic Z, Soprano KJ \& Soprano DR 2009 HACE1: a novel repressor of RAR transcriptional activity. Journal of Cellular Biochemistry 107 482-493. (doi:10.1002/jcb.22146)

Zheng L, Annab LA, Afshari CA, Lee WH \& Boyer TG 2001 BRCA1 mediates ligand-independent transcriptional repression of the estrogen receptor. PNAS 98 9587-9592. (doi:10.1073/pnas.171174298)

Zhu J, Gianni M, Kopf E, Honoré N, Chelbi-Alix M, Koken M, Quignon F, Rochette-Egly C \& de The H 1999 Retinoic acid induces proteasomedependent degradation of retinoic acid receptor $\alpha(\operatorname{RAR} \alpha)$ and oncogenic RAR $\alpha$ fusion proteins. PNAS 96 14807-14812. (doi:10.1073/ pnas.96.26.14807)

Zhu J, Zhao C, Kharman-Biz A, Zhuang T, Jonsson P, Liang N, Williams C, Lin C-Y, Qiao Y, Zendehdel K et al. 2014 The atypical ubiquitin ligase RNF31 stabilizes estrogen receptor $\alpha$ and modulates estrogen-stimulated breast cancer cell proliferation. Oncogene 33 4340-4351. (doi:10.1038/onc.2013.573)

Received in final form 21 April 2015

Accepted 5 May 2015

Accepted Preprint published online 5 May 2015
(C) 2015 Society for Endocrinology Printed in Great Britain
Published by Bioscientifica Ltd. 